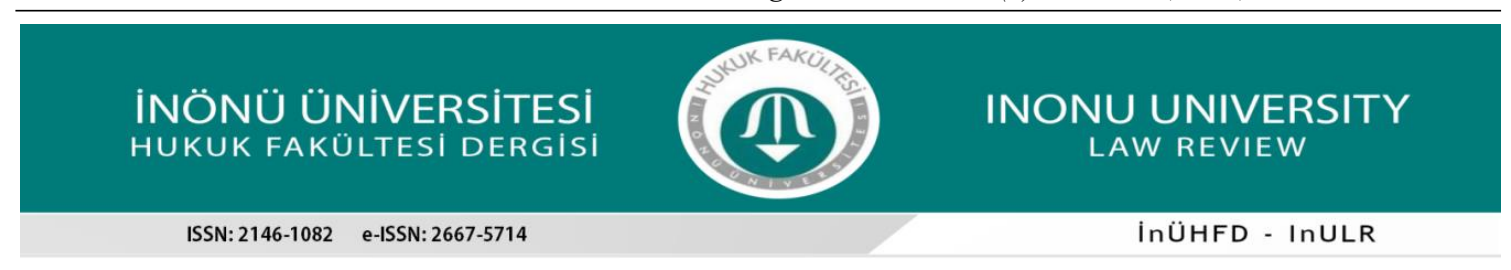

\title{
ETHEREUM VE AKILLI SÖZLEŞMELER
}

\author{
ETHEREUM AND THE SMART CONRACTS
}

\begin{tabular}{l} 
Makale Bilgi \\
\hline Gönderi: 03/01/2021 \\
Kabul : 25/03/2021 \\
Anahtar Kelimeler \\
Blokzincir, \\
Ethereum, \\
Teknoloji, \\
Güven Asimetrisi, \\
Aklll Sözleşmeler
\end{tabular}

\section{Article Info}

Received: 03/01/2021

Accepted: 25/03/2021

\section{Keywords}

Blochchain,

Ethereum,

Technology,

Trust Asymetry,

Smart Contracts.

\section{Mete TEVETOĞLU* $m$ [i]}

Özet

https://dai.org/10.21492/inuhfd.852860

Borcun kaynaklarından biri olan sözleşmelerin temelinde tarafların sözleşme yapmak konusunda iradelerini açıklamaları ve bu iradelerin birbiri ile uyuşması yatar. Sözleşmesel yükümlülüklerin sözleşmelerde düzenlenen şekilde yerine getirilmesi önemlidir. Bu nokta, taraflarının iradelerine tabi olup ve birbirlerine yönelik karşllıklı güvenlerine dayanır. Sözleşmelerin gereği gibi ifası, dayanağı ve kaynağı bakımından hassas, zayıf ve kırılgandır. Zira, taraflar her zaman birbirlerinin iradelerini tam ve doğru şekilde anlayamayabilir. Yine böylesine akitlerde taraflar, aradan geçen zamanın veya değişen şartların etkisiyle yahut ortada bunun için zorlayıcı bir sebep yokken bile sözleşmeye yansıyan iradesine konu taahhüdünü tam veya zamanında yerine getirmekten kaçınabilir. Güven esasına dayanan sözleşmelerin ifası itimat asimetrisi riskine ve taraf iradesinin zaaflarına tabidir. Teknoloji, güven ve sözleşmelerin ifa edilmesine dair bu risklerin giderilmesine çözüm getirebilir mi? İşte bu soru, Bitcoin ile ortaya çıkan Blokzincir teknolojisini pek çok yönden daha ileri taşıyan Ethereum ile birlikte daha fazla tartışılır, merak edilir hale gelmiştir. Ethereum ile beraber tekrar hatırlanan ve Blokzincir teknolojisi ile yeniden yorumlanan akıllı sözleşme kavramı mezkur sözleşmenin, taraflarının karşılıklı, subjektif güvenine mahkum edilmeden, kendi kendini ifa edebilmesinin yeniden tartışılmasına ve heyecanla karşılanmasına yol açmıştır. Bu makalede, Ethereum üzerinde geliştirilebilen ve uygulanabilen akıllı sözleşmelerin ne anlama geldiği, kendi kendini nasıl ifa edebildiği, gelecekteki teknoloji ve hukuk işbirliğine dair hangi etkileşimleri yarattığı ve bunların hukuki sonuçlarına incelenmektedir.

\begin{abstract}
At the basis of the contracts, which are one of the sources of debt, lies the parties' declaration of their will to make a contract and the agreement of these wills with each other. It is important that contractual obligations are fulfilled as set out in contracts. This point is subject to the will of their parties and is based on their mutual trust in each other. Duly execution of contracts is sensitive, weak and fragile in terms of its basis and source. Because the parties may not always understand each other's wills fully and correctly. Again, in such contracts, the parties may refrain from fulfilling their commitment in full or on time due to the effect of the intervening time or changing conditions, or even if there is no compelling reason for this. The execution of trust-based contracts is subject to the risk of trust asymmetry and the weaknesses of the party's will. Can technology solve these risks of trust and fulfillment of contracts? This question has become more discussed and curious with Ethereum, which carries the Blockchain technology that emerged with Bitcoin further in many ways. The smart contract concept, which has been recalled with Ethereum and reinterpreted with Blockchain technology, has led to the discussion and enthusiasm of the mentioned contract's self-performance without being condemned to the mutual, subjective trust of its parties. This article focuses what smart contracts can be developed and implemented on Ethereum mean, how they can self-fulfill, what interactions they create for future technology and legal cooperation, and their legal consequences.
\end{abstract}




\section{GİRIȘ}

Konuya yabancı olanların sıklıkla yanılgıya düştüğünün aksine "smart contracts" yani "akıllı sözleşmeler" ile kastedilen ${ }^{1}$ yeni bir olgu, yeni bir kavram veya yepyeni sözleşme teknolojisi değildir². Aksine, kavram, ilk defa 1994 yllında, Nick Szabo tarafından, ifa aşamasında insan iradesinden arındırılmış ve kendi kendini ifa edebilen sözleşmeler fikri olarak açılanmış, akademik olarak incelenmiş, isimlendirilmiş ve tartışmaya açılmıştır ${ }^{3}$. Aradan geçen, uzun sayılabillen bir zama geçtikten sonra, akıllı sözleşme kavramının yeniden gündeme gelmesi, inceleme, araştırma ve tartışmalara konu olmasının sebebi Blokzincir teknolojisi ve Bitcoin'in ortaya çıkmasını takiben geliştirilen Ethereum'dur ${ }^{4}$. Bu makalede, "Ethereum ve Akıllı Sözleşmeler"in inceleme konusu olarak seçilmesinin temel sebebi, Ethereum'un akıllı sözleşme kavramını gündeme taşıyan bu etkisinin ve aralarındaki ilişkinin sonuçlarının teknoloji ve hukuk ekseninde analiz edilmesidir.

Teknolojinin ilerlemesi, elektronik ticaretten, kripto paralara kadar pek çok alanda olduğu gibi sözleşmeler alanında da etkisini göstermektedir. Zamanla somutlaşan bu etki, sözleşmelerin kurulması ve ifası dahil olmak üzere art arda aşamalarda karşımıza çıkmakta; tarihi oldukça eskiye dayanan sözleşmeler hukukunun temel özelliklerinin, gelişen teknolojilerin ve bunları sağladığı olanakların 1şığında gözden geçirilmesine yol açmaktadır. Kıta Avrupası Hukuk sisteminde ve dolayısıyla Türk Hukuku'nda, sözleşmeler alanındaki yasal düzenlemeler oldukça eskidir. 19. yüzyılın başlarında Avrupa Hukukunda yapılan kodifikasyonları takip eden Türk hukuk sistemi, temelinde nerdeyse 100 yılı bulan yasal düzenlemelerle, hatta belki daha eskisine bakılacak olursa Roma Hukuku'ndan bugüne gelen sözleşme teorilerinin etkileriyle değişen dünyadaki sözleşme ihtiyaçlarını yönetmeye, karşılamaya çalışmaktadır ${ }^{5}$. Buna mukabil, bugün yaşadığımız dünya nüfus, ulaşım, tarım, ticaret, eğitim, iletişim ve finans başta olmak üzere her konuda, teknoloji ile birlikte baş döndürücü bir değişim içerisindedir. Bugünün hayatında her şey hızlı bir değişim ve dönüşüm süreci yaşamakta, bu durum ortaya çıkan yeni teknolojilerin ve bunları sunduğu imkanların her sektörde olduğu gibi hukuk alanında da dikkate alınmasını kaçınılmaz kılmaktadır. Aslında yalın perspektiften bakıldığında; internet, telekomünikasyon, yazılım gibi alanlarda son 20 yılda ikinci, üçüncü, dördüncü versiyonlarını yaşadığımız teknolojik devrimler söz konusudur. İnternet ile başlayarak bir çok yönden devam eden bu yeni teknolojik gelişmelerin her biri, tarihin kronolojik sıralamasında, çağları açıp kapatan değişimler veya devrimler seviyesindedir. Ne var ki bunların aşırı hızlı, seri, ilişskili şekilde ilerlemesinden ve gerçekleşmesinden ötürü on yıllar içinde adeta çağlar defalarca değişirken, devrimsel reformlar yaşanırken, çağları açıp kapamaya dahi firsat bulunamadığını söylemek abartılı olmayacaktır. Bu değişim ve dönüşüm hukuk alanında da bir süredir somut şekilde gözlemlenmektedir. Zira, teknolojide yaşanan gelişmelerin ortaya çıkardığı olanaklar, sözleşmelerin; akdedilmesinden ifasına, sözleşme tiplerinden bunların içerdiği hükümlere kadar, teknolojiden bağımsız kalmasına, uzak durmasına, aynı şekilde muhafaza edilmesine olanak vermemektedir. Yeni teknolojiler vesilesiyle, telefonlar, saatler, binalar, şehirler gibi sözleşmelerin de akıllanması, böylece akıllı sözleşmeler, teknolojik sözleşmeler şeklinde yeni versiyonlarının ortaya çıkması ve tartışılması kaçınılmazdır. Akıllı sözleșmeler fikrinin temelinde, aracılara olan ihtiyacın ortadan kaldırılması ve sözleșmenin kendi kendini ifa etmesi sayesinde tarafların birbirine güvenmek zorunda olmaktan kurtarılması ihtiyacı yatmaktadır. Sözleşmenin yapılması aşamasında ve ifasına dair karşı tarafa güven ihtiyacını ve aracılara yönelik gereksinimi ortadan kaldırma fikriyle akıllı sözleşmeler konusunu bugünkü anlamıyla gündeme taşıyan ve somutlaştıran ise Ethereum olmuştur. Bu sebeple önce Blokzincir ve ardından Ethereum, çok da yeni bir kavram olmayan akıllı sözleşmeleri yeniden gündeme taşımıştır.

\footnotetext{
${ }^{1}$ Bu yazı, 15-16-17 Ekim 2020'de düzenlenen “Borçlar Hukuku Kongresi”nde, 15.10.2020 tarihinde yazar tarafindan sunulan Ethereum ve Akıllı Sözleşmeler (Ethereum and Smart Contracts) başlıklı tebliğin makale olarak kaleme alınmış versiyonudur. Bu makalede "Smart Contracts" ve "Akıllı Sözleșmeler" ifadeleri bir arada aynı anlama gelmek üzere kullanılmıș olup ilgili konuya ve duruma uygunluğuna göre "Smart Contrats" ve "Akı1ll Sözleşmeler" ifadesi tercih edilmiştir.

2 RASKIN, Max: "The Law and Legality of Smart Contracts". Georgetown Law Technology Review 304(2017), 315,320, https://ssrn.com/abstract=2959166 (Erişim Tarihi: 22.10.2020); Wei Dai B-Cash'i, Nick Szabo BitGold'u ve David Chaum Digicash'ı digital paraların en ilkel formları olup merkezi finansal sistemlere yönelik arz ettikleri riskleden ötürü devletler tarafından engellenmiştir. Bitcoin ise bu engellemelerden sakınmak amacıyla mucidinin ve ekibinin gizli kalması tercih edilen bir proje olarak tamamlanmıştır.

3 SZABO, Nick: Smart Contracts (1994), www.fon.hum.uva.nl/rob/Courses/InformationInSpeech/CDROM/Literature/ LOTwinterschool2006/szabo.best.vwh.net/smart.contracts.html (Erişim Tarihi: 15.10.2020)

${ }^{4}$ BUTERIN, Vitalik: "Ethereum: A Next-Generation Cryptocurrency and Decentralized Application Platform (Ethereum)", Bitcoin Magazine, https://Bitcoinmagazine.com/articles/Ethereum-next-generation-cryptocurrency-decentralizedapplication-platform-1390528211 (Erişim Tarihi: 16.10.2020).

${ }^{5}$ ÇEKIN, Mesut Serdar: "Borçlar Hukuku ile Veri Koruma Hukuku Açısından Blockchain Teknolojisi ve Akıllı Sözleşmeler: Hukuk Düzenimizde Bir Paradigma Değişimine Gerek Var Mı?” İstanbul Hukuk Mecmuası, 77(1), 2019, s.318 vd.
} 
Akıllı sözleşmeler kavramını anlamak ve hukuken değerlendirebilmek için öncelikle Blockzincir, Bitcoin ve Ethereum kavramlarını kısaca ve karşılaştırmalı şekilde incelemek, ardından akıllı sözleşmelere neden ihtiyaç duyulduğunu göz önünde bulundurarak, bu sözleşmelerin hukuki yapısını, özellik ve sakıncalarını değerlendirmek gerekir. Zira, bugün akıllı sözleşmeler konusunun yoğun ve yaygın şekilde inceleme, araştırma ve yatırımlara konu edilmesini sağlayan unsurlar anılan terimlerdir 6 .

\section{AKILLI SÖZLEŞMELERIN ORTAYA ÇIKIŞI VE GELIŞMESI}

\section{A. Bitcoin ve Blokzincir}

Akıllı sözleşme kavramının ve Ethereum ile ilişkisinin anlaşılabilmesi için öncelikle Blokzincir, Bitcoin ve Akıllı Sözleşme kavramlarını mümkün kılan bu teknoloji ve unsurları kısaca ele almak gerekir. Zira Ethereum ve Smart Contracts kavramları, aralarındaki ilişkiyle birlikte, bir anda ortaya çıkmış değildir. Bunlar, öncelikle, 1990'lı yıllarda başlayan ve sonrasında hızlanarak devam eden teknolojik çalışmaların ve gelişmelerin etkisiyle ortaya çıkıp şekillenenen Blokzincir ve Bitcoin'in devamında yapılan geliştirmelerin sonuçlarıdır ${ }^{7}$.

Bitcoin ve son birkaç yıldır tüm dünyada yediden yetmişe herkesin hakkında bilgi sahibi olduğu Kripto Paralar, Blokzincir adlı yazılımdan oluşurlar. Yani burada Blokzincir üzerindeki bilgisayar kodları Kripto Paraları oluşturmaktadır. Blokzincir, ağ üzerinden, çok sayıdaki kimliği bilinmeyen kişi tarafından güvenli şekilde tutulabilen, değiştirilemezlik özelliğine sahip veri tabanıdır ${ }^{8}$. Bu veri tabanında, veriler birbirine ardışı şekilde bağlanmış dijital işlemlere ait veri bloklarından oluşur ${ }^{9}$. Blokzincir, Satoshi Nakamoto tarafından, ilk olarak 2008 yılında, eşler arası doğrudan para transferi makalesi ${ }^{10}$ ile ortaya konulmuştur. Bu makaleden hemen sonra Blokzincir ve Bitcoin kavramları hayatımızda kendilerine kalıcı bir yer edinmiştir ${ }^{11}$. Bu noktada, bu iki kavramı hemen birbirinden ayırmak gerekir. Blokzincir ve Bitcoin çoğunlukla birbiriyle karıştırılmakta, birbirinin yerine kullanılmaktadır. Halbuki bu ikisi biribinden farklı kavramlardır. Kısaca açıklamak gerekirse; Bitcoin, Blokzincir üzerindeki bir para birimidir. Diğer bir ifadeyle Bitcoin dijital bir varlık birimi olarak karşımıza çıkmaktadır. Bitcoin'in temelindeki teknoloji ise Blokzincir'dir. Blokzincir teknolojisinde, ağ üzerinde Blokzincir ağına giren kullanıcılar, birbirlerindeki bilgi ve verileri görebilmektedir. Bunun yanı sıra kullanıcılar, diğer kullanıcıların işlem ve işlem eşlerini de görebilmekte, inceleyebilmekte ve onaylayabilmektedir. Dolayısıyla bu teknoloji, 1990 yılından sonra ortaya çıkan, ağ üzerinde kullanıcıların arasında doğrudan dijiral veri transfer yapma olanağ 1 veren dosya paylaşım programı dediğimiz programın altyapısına benzerlik arz etmekte; dağıtık şekilde, farklı bilgisayarlarda, aynı verilerin, ağdaki kullanıcılar tarafından görülebilmesini ve onaylanabilmesini sağlayan bir teknoloji sunmaktadır. Bu açıkamaların ışığında ele aldığımızda; Blokzincir teknolojisi, bloklardan oluşan bir zinciriifade eder. Blokların içerisinde ise işlem verileri ve bilgiler bulunmaktadır. Bu işlemler veya veriler ağdaki diğer kullanıcılar tarafından, doğruluk bakımından onaylandıklarında, örneğin; \%51 kullanıcı tarafından onaylandıklarında, daha önceki blok ile bir araya getirilir ve bir bütün halinde şeffaf, değiştirilemez, sabit ve denetlenebilir bir zincir şeklinde Blokzincir'in ortaya çıkmasını sağlarlar ${ }^{12}$.

\footnotetext{
${ }^{6}$ KAKAVAND, Hossein /KOST DE SEVRES, Nicolette/CHILTON, Bart: The Blockchain Revolution: An Analysis of Regulation and Technology Related to Distributed Ledger Technologies (January 1, 2017), s.2 http://dx.doi.org/10.2139/ssrn.2849251, (Erişim Tarihi: 14.10.2020); KARAMANLIOĞLU, Argun: "Concept of Smart Contracts - A Legal Perspective”, Kocaeli Üniversitesi Sosyal Bilimler Dergisi, (35)2018, s.35.

${ }^{7}$ CHOHAN, Usman W.: A History of Bitcoin (September 30, 2017), s.1-7, http://dx.doi.org/10.2139/ssrn.3047875 (Erișim Tarihi: 15.10.2020); HÄRDLE, Wolfgang K./HARVEY, Campbell R./REULE, Raphael C. G.: Understanding Cryptocurrencies (March 26, 2019), s.3-5, http://dx.doi.org/10.2139/ssrn.3360304 (Erișim Tarihi: 18.09.2020).

8 TEVETOĞLU, Mete: ICO (İlk Dijital Para Arzı) ve Yatırımcının (Katılımcının) Korunması, Sektörel Bazda Tüketici Hukuku Uygulamaları 2020, İstanbul 2020, s.88.

${ }^{9} \mathrm{Bu}$ bloklarda veri bulunmakta olup hava durumu, hasat miktarı, kira ödeme tarihi veya bir müzik listesi gibi herhangi bir veri Blokzincir üzerinde tutulabilmektedir.

10 Makalenin orjinal metni için bkz. https://Bitcoin.org/Bitcoin.pdf ve makalenin Türkçe tercümesi için bkz. https://medium.com/bili\%C5\%9Fim-hareketi/her-\%C5\%9Feyi-ba\%C5\%9Flatan-makale-Bitcoin-pdf-b326e4c09250 (Erişim Tarihi: 16.10.2020)

11 HÄRDLE/RAPHAEL/REULE, s.7; CROSBY, Michael/PATTANAYAK, Pradan/VERMA, Sanjeev/KALYANARAMAN, Vignesh: "BlockChain Technology: Beyond Bitcoin", Applied Innovation Review, (2), June 2016, s.9 (https://j2-capital.com/wp-content/uploads/2017/11/AIR-2016-BlockChain.pdf (Erişim Tarihi: 11.09.2020); TEVETOĞLU, s.89.

${ }^{12}$ Ağdaki veriye erişim ve ağda veri transferi için kullanılan "Public Key" IBAN Numaasına ve "Private Key" ise Pin Koduna benzetilmektedir. Bu iki kavram aynı zamanda Bitcoin başta olmak üzere Blokzincir üzerindeki örneğin Bitcoin gibi bir kripto
} 
Öte yandan, özelliklerini kısaca ele aldığımız ve önemli devrimsel etkileri bulunan Blokzincir de, tıpkı İnternet gibi akıllı sözleşmeler için tasarlanmış bir protokol değildir. Zira, Blokzincir; aslında ağ üzerinde kullanıcıların birbirlerine, aracısız, merkeziyetsiz ve doğrudan varlık transferi, yani Bitcoin transferi yapabilmelerini sağlayan teknolojik altyapıdır ${ }^{13}$. Bu açıdan, bir yazılımdan bahsettiğimiz anlaşılmaktadır. Bu yazııımı anlamak için, standart yazılımlardan farkını vurgulamak gerekir. Bu fark, ağ üzerindeki kullanıcıların mutakabat sistemini kendilerinin sağlamalarıdır. İşlem ve mutabakatların merkeziyetsiz, şeffaf ve doğrudan varlık transferi yapılmasına imkân sağlayan altyapıya gerçekleştirilmesidir. Bitcoin, böylece zaman içinde hem sanal para biriminin adı hem de adeta programın adı halini almış, temelinde ise Blokzincir yatan özgün teknolojidir. Oysa, Blokzincir'de yalnızca finansal işlemlerin yapılması söz konusu değildir. Bunun yanı sıra herhangi bir verinin kalıcı şekilde kaydedilmesi amacıyla programlanabilen, merkezi bulunmayan, dağıtık yani farklı bilgisayarlara yayılmış bir defter, veri tabanı söz konusudur. Blokzincir yazılımı, aracı kurum veya merkezi mutabakat sistem yahut uygulaması olmaksızın dijitalleştirilmiş varlıkların taraflar arasında doğrudan transfer edilmesini sağlayan yöntemdir. $\mathrm{Bu}$ yöntem, merkeziyetsizlik, aracısızlık, değiştirilemezlik gibi özellikleriyle, pek çok sektör ve hukuki işlem türü bakımından, büyük bir devrimdir ${ }^{14}$. Akıllı sözleşme konseptinin iki temel hedefi vardır. Birinci hedef, aracıların ortadan kaldırılmasıdır. İkinci ise hukuki işlemlerin mümkün olduğunca, taraflarının birbirlerine duyacakları güvene muhtaç olmaktan kurtarılmasıdır. Blokzincir, birinci hedef olan aracıların ortadan kaldırılmasına olanak sağlamış ve bunu Bitcoin ile ispat etmiştir. Fakat ikinci hedef ve ihtiyaç olan güven asimetrisinin aşılması bakımından, hala kendi kendini ifa eden bir sözleşmenin nasıl ve hangi platformda mümkün olacağı noktasını aydınlamış değildir. İkinci hedef ancak Ethereum'un geliştirilmesi ile sağlanabilmiştir.

\section{B. Ethereum ve Akıllı Sözleşme İlişkisi}

Bitcoin'in temelinde yatan Blokzincir teknolojisi ve felsefesi, Rus yazılımcı Vitalik Buterin tarafından, Ethereum ${ }^{15}$ ile birlikte, 2013 yılında geliştirilmiş, belki bir belki bir kaç adım daha ileriye taşınmıştır. Böylece Buterin, Blockchain'in kullandı̆̆ sertifikayı değiştirmiş ve SHA-256 sertifikasıyla Blockchain temelli yazılım olan Ethereum'u geliştirmiştir. Ethereum ise akıllı sözleşma olarak adlandırılan, kodlardan oluşan dokümanların üretilebilmesine olanak sağlamıştır ${ }^{16}$. Kısa ve anlaşılabilir bir şekilde izah etmek gerekirse; fonksiyon olarak, akıllı sözleşme, tarafların üzerinde önceden mutabakata vardıkları sözleşme şartlarının gerçekleşmesi halinde sözleşme konusu edimlerin tarafların ek bir tasarrufuna bağlı olmaksızın otonom bir biçimde, yani kendiliğinden ifa edilmesini ifade eder ${ }^{17}$. Bu fonksiyon, bir sözleşme yaparken karşı tarafa güvenilmesine dair gereksinimini ve ifanın bir tarafın tasarrufuna bağlı olmasının yarattığı belirsizliği aşmayı hedefler. Konunun daha iyi ortaya konulabilmesi için öncelikle akıllı sözleşme kavramını bugünkü anlamıyla mümkün kılan Ether ve Ethereum kavramları incelenmelidir.

Ethereum, kamuya açık ve zincir modellemesiyle hesap yapan, açık kaynaklı protokol veya daha doğru ifadeyle işletim sistemidir. Ether ise bu platform tarafından üretilen kripto para birimine verilen addır, tıpk1 Blokzincir ve Bitcoin gibi. Etherum'un Solidity ${ }^{18}$ yazılım dilini kullanan, farklı sertifikalarla geliştirilmiş yapısı Ethereum üzerinde Smart Contracts adı verilen ve yazılımdan oluşan kod parçalarının yerleştirilmesine ve çalışmasına olanak sağlamıştır ${ }^{19}$.

paranın veya diğer bir verinin hem zilyetliğini tesis eden bir araç hem de zilyetliğin mülkiyete birkarine oluşturmasından ötürü mülkiyetin ispatını, mülkiyet üzerinde tasarrufu mümkün kılan araçlardır.

${ }^{13}$ ATZORI, Marcella: Blockchain Technology and Decentralized Governance: Is the State Still Necessary? (December 1, 2015), s.8-10, http://dx.doi.org/10.2139/ssrn.2709713 (Erişim Tarihi: 07.09.2020)

${ }^{14}$ BLEMUS, Stéphane: Law and Blockchain: "A Legal Perspective on Current Regulatory Trends Worldwide (January 17, 2018)", Revue Trimestrielle de Droit Financier (Corporate Finance and Capital Markets Law Review) RTDF N4-2017 December 2017, http://dx.doi.org/10.2139/ssrn.3080639, s.4-7, (Erişim Tarihi: 18.11.2020); KAKAVAND/KOST DE SEVRES/CHILTON, s.8; TEVETOĞLU, s.89-90.

${ }^{15} \mathrm{https}$ ///www.Ethereum.org/beginners/ (Erişim Tarihi: 20.10.2020)

${ }^{16}$ BLEMUS, s.8; PILAVCI, Ezgi Elife: "The Regulation of Smart Contracts: Law, Governance and Practice”, İstanbul Bilgi Üniversitesi, Lisansüstü Programlar Enstitüsü - Bilişim ve Teknoloji Hukuku Yüksek Lisans Programı (Yayınlanmamış Yüksek Lisans Tezi), İstanbul 2019, s.14.

${ }^{17}$ Basit bir tanıma göre Akıllı Sözleşmeler, en basit şekilde, "kendi kendini yerine getiren çalıştırılabilir bilgisayar programları formunda elektronik talimatlar" olarak tanımlanabilir (Bkz. O'SHIELDS, Reggie: "Smart Contracts: Legal Agreements for the Blockchain", North Carolina Banking Institute, 21(1), Article 11, (2017), s179.)

${ }^{18} \mathrm{https} / / /$ docs.soliditylang.org/en/v0.5.3/ (Erişim Tarihi: 12.0.2020); Solidity, akıllı sözleşmelerin uygulanması için nesne yönelimli, üst düzey bir dildir. Akıllı sözleşmeler ise Ethereum üzerindeki hesapların davranışını yöneten programlardır.

${ }_{19}^{19}$ BUTERIN, Vitalik: "Bitcoin Is Not Quantum-Safe, And How We Can Fix It When Needed (Bitcoin)", Bitcoin Magazine, https://bitcoinmagazine.com/articles/bitcoin-is-not-quantum-safe-and-how-we-can-fix1375242150 (Erişim Tarihi: 
Akıllı Sözleşme kavramı ile, taraflar arasında "Self-Executing" yani "Kendi Kendini İfa Etme" özelliğine sahip, bir tarafın sözleşme konusu hakkını elde etmesi için diğer tarafın ona bu hakkı sunmasına muhtaç veya diğerine güvenmek zorunda olmadığ sözleşmeler ifade edilmektedir ${ }^{20}$. Bu kavram Ethereum ile bugünkü modern formuna kavuşmuşsa da ilk defa Ethereum ile ortaya çıkmış değildir.

Smart Contracts kavramı ilk defa 1994 yılında bir hukuk profesörü olan Nick Szabo'nun yaptığı çalışmalar neticesinde ortaya çıkmış ve zaman içinde şekillenerek bugünkü halini almıştır. Nick Szabo, sözleşme yapımında; asitmetrik güven ilişkisinin ortaya çıkarmış olduğu sorunların giderilmesi ihtiyacının zaman içerisinde artacağını öngörmüştür ${ }^{21}$. Çünkü bugün sözleşme, hukuken en yalın ifadeyle tarafların iradelerinin akdin yapılması konusunda uyuşmasını ifade eder. Taraflar, sözleşmenin esaslı unsurlarına dair karşılıklı açıkladıkları iradeleriyle birbirlerine uyum gösterdikleri takdirde sözleşmenin varlığından bahsedebiliriz ${ }^{22}$. İrade ise karşılıklı güven esasına göre beyan edilen ve karşı tarafın beyan ettiğini yapacağına dair inanç ve güvenle şekillenen unsurudur. Diğer bir ifadeyle, tarafların sözleşme için ön görüşmelere başlanmaları için bile, evvela diğer tarafin, o sözleşmeye konu edilecek iş veya işlemleri yapacağına dair inanca, en azından asgari seviyede güvene sahip olmaları gerekir. Müzakere esnasında bu inanç korunursa, pekişir ve sözleşmenin şartlarında mutabakata varılırsa, sözleşmenin akdedilmesi mümkün olur. Sözleşmenin konusu olan taahhütler, ifa edilip edilmeyeceği henüz belirsiz olan vaatlerdir. Bu vaatlere değer katan husus, tarafların birbirlerine olan güvenleri; güveni esas alarak biçimlenen, açıklanan iradelerdir. Ancak hukuk uygulaması ve uyuşmazlık tarihçesi gösteriyor ki, güven asitmetriktir. Akdin kurulduğu anda tarafların serbest iradeleriyle taahhüt ettiği işi veya işlemi, ifa edip etmeyeceği henüz bilinmemektedir. Ani edimli sözleşmeler ayrı tutulacak olursa, iradenin açıklandığı andan, ifanın gerçekleşeceği ana kadar geçecek olan süre boyunca, tarafların psikolojileri, sağlık şartları, genel ekonomik koşullar, yürürlükteki yasalar veya siyasal faktörler sürekli hareket ve değişim içindedir. Tüm bu değişkenler veya muhtemel yorum farklılıkları, sözleşmenin akdedildiği yahut bir tarafça anlaşıldığı haliyle, tam ve zamanında, yerine getirilip getirilmeyeceğine dair belirsizliklere ve tereddütlere yol açar. Pek çok kişi veya kurumun, sözleşmeyle taahhüt ettiği yükümlülükleri, ifa zamanı geldiğinde, eksiksiz şekilde yerine getirmediği, getiremediği, eksik veya geç yerine getirdiği yahut farklı şekilde yorumlama eğilimi gösterebildiği bir vakıadır. Kaldı ki bir tarafın ortada hiçbir sebep yokken sözleşmeyi ihlal etmesinin önünde de engel yoktur. Sözleşmesel uyuşmazlıkların temelinde, gerçekleşeceğine inanılan, karşı taraf beyanına ve tasarrufuna tabi olan yükümlülüğün ifa edilmemesi, eksik ifa edilmesi, geç ifa edilmesi veya yorum farklılıkları yatmaktadır. Açıkçası bunca riske ve belirsizliğe tabi olan sözleşmelerle hukuki ilişkileri veya ticaret hayatını yöneltmek katlanılması zor, oldukça riskli bir durumdur. Bu sebeplelerle, teknolojinin hukuk alanındaki uygulaması önem arz etmekte, dikkat çekmektedir. Böylece, akı1lı sözleşmelerin varlık sebebi ve temel fonksiyonu; sözleşmelerin, güven unsurunun yol açtığ belirsizliklerden, risklerden arındırılması, tarafların haklarının daha etkin şekilde temin edilmesi olarak ifade edilebilir ${ }^{23}$.

Sözleşmelerin ifa edilmesinde güven asimetrisinin olası olumsuz sonuçlarını arttıran diğer bir faktör ise aracılardır. Aracıların yer aldığı sözleşmelerde tarafların birbirlerine olan güvenlerini aracılar tesis eder. Ancak bu durum, tarafların doğrudan iletişimini azaltarak, hem birbirlerini tam ve doğru anlamamalarına yol açabilir hem de onları aracılık prosedürlerine ve maliyetlerine tabi kılar. Sözleşmenin türüne göre; avukatlara, emlakçılara, bankacılara, aracı kurumlara, işlem bazında broker

21.08.2020); SEC, “The DAO” Investigative Report, 25 Temmuz 2017, s.3, https://www.sec.gov/litigation/investreport/3481207.pdf (Erişim Tarihi: 17.06.2020)

${ }^{20}$ BROWNSWORD, Roger: "Regulatory Fitness: Fintech, Funny Money and Smart Contracts", European Business Organization Law Review (20), 2019, s.5-27, https://core.ac.uk/download/pdf/195262705.pdf, s.6-8 (Erișim Tarihi: 09.12.2020); SCHREPEL, Thibault: "Collusion by Blockchain and Smart Contracts", (January 14, 2019), Harvard Journal of Law and Technology (33 Harv. J.L. \& Tech.) http://dx.doi.org/10.2139/ssrn.3315182, s.24,25,36 (Erişim Tarihi: 16.10.2020); RASKIN, s.309 vd; TEVETOĞLU, s.90; Akıllı Sözleşme kavramına dair ilk makale için SZABO, Nick: Smart Contracts: Building Blocks for Digital Markets https://nakamotoinstitute.org/the-idea-of-smart-contracts/ (Erişim Tarihi: 10.10.2020) ve güncel bir tanım için bkz. TBV Blokchain Turkey Platformu, Blokzinciri Teknolojisi Terminoloji Çalışması, Hukuk, Düzenlemeler ve Kamu İlişkileri Çalışma Grubu Raporu, İstanbul 2019, s.10; Bu tanıma göre; "Blokzinciri ağı üzerinde yer alan veriler üzerinde sınıları önceden belirlenen bir akış içerisinde işlem yapılmasını sağlayan ve güvenli bir bilgisayar ağı tarafından doğrulanan merkezi olmayan platformu ifade etmektedir. Hukuki bağlayıcılık taşımayan akıllı sözleşmeler, tarafların zincirin içeriği hakkında anlaşarak kriptografik olarak imzalanmasıyla Blokzinciri ağına yüklenmektedir."

${ }^{21}$ BLEMUS, s.16.

${ }^{22}$ OĞUZMAN, M. Kemal/ÖZ Turgut, Borçlar Hukuku Genel Hükümler, C. I, İstanbul, 2020, s.242; TAŞKIN Zeynep Damla, Sözleşmenin Kurulması, İstanbul 2020, s.189.

${ }^{23}$ DIMITROPOULOS, Georgios: “The Law of Blockchain”, Washington Law Review, 95(1117), 2020, s.1135-1136. 
şirketlere ihtiyaç duyulmaktadır. Bu noktada Szabo'nun ortaya attığı teori, güven asimetrisini tamamen ortadan kaldıran, tarafların güvene ve aracılara ihtiyaç kalmadan açıkladıkları iradeleri zamanı geldiğinde ve şartları gerçekleştiğinde kendi kendine icra edebilen kontratların geliştirilmesi ve hizmete sunulması fikrini ifade etmektedir ${ }^{24}$.

Szabo, akıllı sözleşme fikrini akıllı otomatlarla açıklamaktadır. Buna göre, akıllı sözleşmeleri en iyi açıklayan, konuya dair ilk örnek; havaalanları, tren garları gibi kamuya açı mahallerde karşımıza çıkan, içine belirtilen miktarda para atıldığıdna kullanıcılarına içecek veya yiyecek gibi ürünleri veren makinalardır. Bu makinalar, akıllı sözleşmelerin ilk ve en basit örnekleridir. Szabo, otomatları emsal alarak akıllı sözleşme kavramını, bir yiyecek veya içecek otomatıyla açıklamaktadır. Buna göre, bu otomatlar, bahse konu işlevleri açısından, birer sözleşme makinesidir. Makinanın sahibi olan taraf, sözleşme yapmaya dair açık ve sabit şekilde icabını kolayca anlaşılır şekilde formüle ederek diğer tarafa sunmaktadır. Bunu fiyat, miktar, ürün gibi bilgileri makineye entegre ederek sağlamaktadır. Diğer taraf ise, buna iltihak etmek için gereken şartları sağladığında, yani önceden belirlenmiş ücreti makinaya attığında, sözleşme kurulur. $\mathrm{Bu}$ sözeşmenin özelliği, sözleşmenin kuruluşunda ve ifasında herhangi diğer bir kişinin aracıllğına yahut tarafların herhangi başka tasarrufuna gerek duyulmadan otomatik şekilde ifa etmesidir ${ }^{25}$.

Böylece, otomak örneğinde olduğu gibi akıllı sözleşmeler söz konusu olduğunda artık aracıya, taraflardan birinin iradesine, bu ürünün teslim edilip edilmeyeceğine dair bir güven ilişkisine ihtiyaç kalmamaktadır. Bu temele dayanan Akıllı Sözleşme kavramı, 1994 yılından sonra çok geliştirilmiş ve Blockchain ile Bitcoin teknolojisiyle ve arkasından da Ethereum ile beraber bugünkü şeklini almış, kısa sürede hukuk ve teknoloji dünyasında uzun seyahat yapmışıır ${ }^{26}$.

\section{C. İnternet Akılı Sözleşmeler İçin Alternatif Olabilir mi?}

Blokzincir veya Ethereum kavramlarının yerine Smart Contracts için alternatif olarak İnternet akla gelebilir. İnternet teknolojisi kendi kendini ifa eden sözleşmeler için yeterli olamaz mı? Sadece İnterneti kullanarak, Blokzinciri veya Ethereum kullanmadan akıllı sözleşme yapmak, bunun kendi kendini ifa etmesini sağlamak mümkün müdür? Bu soruların cevabı kısaca olumsuzdur. Tek başına İnternet alt yapısı ve teknolojisi kendi kendini ifa edebilen akıllı sözleşmeler için uygun ve yeterli değildir. Zira, internet aslında temelinde sadece iletişim protokolüdür. İnternet, bir e-ticaret protokolü ve sözleşme protokolü değildir. İnternet, Web 1.0 ve Web 2.0 örneklerinde interaktif veya tek taraflı etkileşim ekseninde gerçekleştirilirken aslında iletişim protokolüdür ve bilgi paylaşım alt yapısıdır ${ }^{27}$. İnternet, sözleşme protokolü veya sözleşmeyi ifa etme yahut ödemeyi gerçekleştirme protokolü olarak tasarlanmamıştır. Bu bakımdan internet, tek başına e-ticaret ve ödeme teknolojisi olmayıp, Akıllı Sözleşme kavramı internetten çok sonra, Blokzincir teknolojisiyle birlikte gündeme gelmeye başlamıştır. Bu şekilde kendi kendini ifa eden, ödeme veya bir edimi ifa etme olanağına sahip sözleşme yazılımından bahsetmek mümkün olmuştur ${ }^{28}$.

\section{Mortgage Krizi ve Dağıtık Defter Teknolojisi (DLT)}

Ethereum ve akıllı sözleşmelere dair yukarıda yer verdiğimiz kavramların özelliklerine ve gelişimine dair değerlendirmelerden sonra akıllı sözleşme fikrinin Ethereum ile birlikte ilgi konusu olmasının ve talep görmesinin altında yatan dönemsel koşulları da kısaca ele almak uygun olacaktır.

Sözleşmelerin akdedilmesinde aracılara duyulan ihtiyaç zorunluluklardan kaynaklanır. Tarafların aracılık maliyetlerine katlanmasının, finansal işlemler bakımından bu kurumların güven kurumları olması şeklinde varsayımsal ve yapay bir gerekçesi söz konusudur. Oysa aracılar güveni arttıran değil azaltan bir etkiye sahiptir. Tarafların arasında sözleşmenin ifasına dair karşılıklı güven bakımından somut olarak ölçülmesi güçlük arz eden orantısızlık her zaman mevcuttur. Bu güven asimetrisinin beraberinde getirdiği belirsizlikler ve hoşnutsuzluklar, 2008'de başlayan ve 2012'ye kadar daramatik bir şiddetle devam eden meşhur Mortgage Krizi sırasında ve sonrasında zirve noktasına ulaşmışıır' ${ }^{29}$. Mortgage krizi, Dağıtık Defter Teknolojilerinin ortaya çıkışıyla ${ }^{30}$ aynı zamana

\footnotetext{
${ }^{24}$ BROWNSWORD, s.10,19.

${ }^{25}$ BLEMUS, s.18; DIMITROPOULOS, s.1126; BROWNSWORD, s.20-21.

${ }^{26}$ SZABO,1994.

${ }^{27}$ KARAMANLIOĞLU, s.31; ÇEKIN, S.320.

28 SCHMITT, Gregor/MLADENOW, Andreas/STRAUSS, Christine/SCHAFFHAUSER-LINZATTI, Michaela: Smart Contracts and Internet of Things: A Qualitative Content Analysis using the Technology-Organization-Environment Framework to Identify Key-Determinants, s.190-191, https://www.sciencedirect.com/ (Erişim Tarihi: 22.10.2020)

${ }^{29}$ TUNALI, Halil: “Mortgage Sistemi: Temelleri, Gelişimi ve Krizi”, İstanbul Üniversitesi İktisat Fakültesi Mecmuası, 58(1), 2011, s.117.

${ }^{30}$ ŞEN, Faruk: "Dağıtık Kayıt Teknolojisi”, Gümrük ve Ticaret Dergisi, 6(17), 2016, s.87-88.
} 
denk gelmiş; krizin aracılara ve finansal piyasaya karşı derinleştirdiği güven kaybı; önce Blokzincir'e, Bitcoin'e ve devamında Ethereum sayesinde akıllı sözleşmelere olan ilgiyi arttırmışıır' ${ }^{31}$.

Öncelikle, Blokzincir modelinin, 1990'lı yıllarda ortayan çıkan, "Distributed Ledger Technology" denen Dağıtık Defter Teknolojisi kavramı olarak karşımıza çıkmaya başladığını belirtmek gerekir. Dağıtık Defter Teknolojisi, bilgi ve verilerin ağ üzerindeki farklı "Node (Düğüm)" denilen, farklı kullanıcıların bilgisayarlarında saklanması ve korunmasını sağlayan bir teknolojidir. Diğer bir şekilde ifade etmek gerekirse; burada, bilginin ve verinin ă̆ üzerindeki farklı bilgisayarlarda eş zamanlı ve eş içerikli şekilde saklanması, korunması, aktarılabilmesi ve kullanılmasını sağlayan bir teknoloji söz konusudur. İlk haliyle bu fikir ve teknoloji, 1991 yılından itibaren, dosya paylaşım programlariyla ortaya konulmuştur ${ }^{32}$.

Ardından bu teknolojiyi işleyen ve geliştiren birçok kurum ve kuruluş, 2008 Mortgage krizinden sonra bankalara, emlakçılara, avukatlara, aracılara ihtiyaç duyulmadan tarafların kendi aralarında doğrudan varlık transferi yapabilmesini sağlayan bir teknolojiyi geliştirmeyi hedefleyerek çalışmalarını sürdürmüşlerdir.

Mortgage krizi, insanlara bankaların bir anda çökebileceğini acı bir şekilde hatırlatmıştır. Finansal kurumların taahhüt ettiği ödemeleri yapamayabileceğini tecrübe ettirmiştir. Aracı kurumların çökmesinin veya taahhütlerini yerine getirmemesinin ihtimal dahilinde olduğunu, sahip olunan güven asitmetrisinin aslında zincirin en zayıf halkası olduğunu gözler önüne sermiș ve dolayısıyla bu aracıları aradan çıkartarak doğrudan ve kendi kendini ifa edebilir sözleşmelerin ve işlemlerin mümkün olup olamayacağının daha çok tartışılmasına yol açmıştır. Nihayet, 2008 finansal krizi, Satoshi Nakamoto takma adıyla yayınlanan Bitcoin White Paper'ında eşler arasında aracıya ihtiyaç duymadan doğrudan varlık transferini sağlayan teknolojinin, Blockchain, Bitcoin, Ethereum ve akı1ll sözleşme kavramlarının ortaya çıkmasını ve gelişmesini tetikleyen temel faktördür.

\section{AKILLI SÖZLEŞMELERIN ÖZELLIKLERİ}

\section{A. İlk Bitcoin İşlemi ve Ethereum'un Ortaya Çıkışı}

İlk Bitcoin işlemi 2009 yılında yapıld1 ${ }^{33}$. Hemen ardından Bitcoin'in klasik para ile karşılaştırmaları başladı. Bitcoin, değeri ve Bitcoin'e olan talep artmaya başlayınca daha çok gündeme geldi. 2012 yılında ise, Blokzincir artık ödeme işlem platformuna dönüşmeye başladı. 2014 yılında Blokzincirin sözleşmelerin yapılmasına, kullanılabilip, kullanılamayacağına dair tartışmalar giderek arttı. Nitekim 2013-2014 yıllarında, bugünkü anlamıyla Akıllı Sözleşme kavramının ortaya çıkmasına imkan sağlayan, İsviçre merkezli Ethereum şirketini kuran ve bu alanda çalışmalar yapmaya başlayan Rus asıllı Vitalik Buterin tarafından Ethereum Blokzinciri tamamlandı ve kullanıma açıldı ${ }^{34}$.

\section{B. Akıllı Sözleşme Kavramı Açısından Bitcoin'in Ethereum ile Karşılaştırılmasıı}

Bitcoin ile Ethereum arasındaki hem benzerlikler hem de farklılıklar akıllı sözleşmelerin Ethereum üzerinde oluşturulan programlarla çalıștıılmasını mümkün kılan unsur ve faktörlerdir. Öncelikle şunu ifade etmek gerekir ki; Bitcoin Blokzincir altyapısındaki paradır. Ethereum da aynı şekilde, Blokzincir yapısıdır. Fakat Ethereum'un Bitcoini "ETH” ifadesi ile kısaltılan paradır. Dolayısıyla Ethereum, Blokzincir yapısıdır ve Blokzincir yapısı olarak, Bitcoinin Blokzinciri ile benzer özellikler gösterir. Esasen burada, Bitcoin Blokzincirinin Ethereum tarafindan geliştirilmesi ve yeni

\footnotetext{
${ }^{31}$ O'SHIELDS, s. 177-178.

32 Dağıtık Defter Teknolojisi genel olarak Blokzincir olarak bilinmektedir. Bu iki kavram sık sık bir birinin yerine kullanılmaktaysa da birbirinden farklıdır. Her Blokzincir bir Dağıtık Defterdir. ancak her dağıtık defter bir Blokzincir değildir. Dağıtık defter teknolojisinin geçmişi internet üzerinden bilgi, eposta, müzik yada dosya paylaşma gibi uygulamalar kadar eskidir. Tabi ki bugünkü haliyle kullanıcıların arasında para başta olmak üzere dijital varlıkların transferini güvenli bir şekilde saplayan değer transfer uygulamasına dair dağıtık defter ise Satoshi Nakamoto'nun 2008 yılında yayımladığı 'Bitcoin: A Peer-to-Peer Electronic Cash System' adlı makaleye dayanmaktadır (ŞEN, s.88). Biliyoruz ki; Napster ve diğer örneklerde olduğu gibi ağ üzerindeki farklı bilgisayar kullanıcıları birbirlerinin bilgisayarlarındaki dosyaları, bilgileri ve belgeleri dosya paylaşım programlarıyla görebilirler ve paylaşabilirlerdi. Daha sonra bu durum Telif Hukuku'na ait pek çok tartışmaya uyuşmazlı̆̆a (Bkz. A\&M Records, Inc. v. Napster, Inc., 239 F.3d 1004 (9th Cir. 2001 - https://www.copyright.gov/fairuse/summaries/a\&mrecords-napster-9thcir2001.pdf Erişim Tarihi: 24.09.2020) ve soruna neden oldu. Çünkü daha çok sinema filmleri ve müzik eserlerinin dünyanın her tarafındaki kullanıcılar tarafından birbirleri arasında paylaşılması gibi uygulamalar ortaya çıkmıștı. Ancak bu teknoloji, dağıtık defter teknolojisine (distributed ledger technology) uygun bir altyapının oluşma ya başlamasının ilk adımlarıydı.

${ }^{33}$ İlk Bitcoin işlemi, 12 Ocak 2009 tarihinde Hal Finney'in Satoshi Nakamoto'dan 10 BTC almasıyla yapıldı. Tarihteki ilk Bitcoin işlemi, Finney'in tarihi "Running Bitcoin" tweet'ini 11 Ocak 2009'da yayınlamasından sadece bir gün sonra gerçekleşmiştir (https://twitter.com/halfin/status/1110302988?). Sistemin ilk blokunun adı "Genesis Block" olarak isimlendirilmiştir ve 4 Ocak 2009'da üretilmiştir.
}

${ }^{34}$ DIMITROPOULOS, s.1122,1126. 
özellikler kazandırılmasıyla ortaya çıan yeni Blokzincirden bahsetmekteyiz. Blokzincirlerden bahsetmişken; Ethereum ve Bitcoini karşılaştırmadan önce söylemek gerekir ki; Blokzincirler iki türdür. İlki, "Public Blockchain" dediğimiz herkesin katılımına ve kullanımına açık olanlar; ikinci ise ise, herkesin kullanımına açık olmayan sadece yetkilendirilmiş sınırlı sayıda kişiler tarafından kullanılabilen, "Private Blockchain" denilen kamuya açık olmayan Blokzincir ağlarıdır. Burada bahsettiğimiz Bitcoin ve Ethereum Blokzinciridir ve Public niteliktedir, yani kamuya açıktır ${ }^{35}$.

Ethereum, Bitcoin Blokzincirine benzeyen bir sistem kullanmaktadır. Bu iki sistem de kamusal kullanıma açık ve tüm işlem geçmişinin merkeziyetsiz şekilde dağıtık olarak kopyalanıp tutulduğu Blokzincirlerdir. Ethereum platformunun Bitcoinden önemli bir fark1; temel kodlama programının Solidity ${ }^{36}$ adı verilen farklı bir kodlama altyapısına sahip olmasıdır. Yine SHA-256 dediğimiz farklı bir algoritma kullanan Bitcoine göre Ethereum'un kendi özel algoritması olduğunu görmekteyiz. Bu kodlamada ve güvenlik sertifikasındaki algoritma farklılığ yapıs1 olmasına rağmen Ethereum'un üzerinde akı1lı sözleşmelerin ortaya çıkabilmesine ve bu sözleşmelerin kod şeklinde önceden belirlenen koşullar gerçekleştiğinde kendi kendine varlık transferi yapabilmesini sağlayan bir özellik kazandırmaktadır ${ }^{37}$.

Bitcoin ve Ethereum'un arasında, yukarıda belirtilenlere ilave olarak, zaman, teknolojik tecrübe, algoritmalar ve yazılımsal bakımdan farkılıklar bulunmaktadır. İşlem hızı açısından bakıldığında; Bitcoin Blokzincirinde bir blok ortalama 10 dakikada üretilmektedir. Ethereum'da ise 15 saniyede bir blok üretilmesi mümkündür. Bitcoin'in toplam adeti yani arz edilen miktarı azami 21 milyon ile sınırlandırılmıştır. Ethereum arzında böyle bir sınırlandırma, üst had söz konusu değildir. Yine Bitcoin'de her blok 1 MB ile sinılıdır. Ethereum'da ise GAS denilen işlem maliyeti ile sınırlandırma söz konusudur ${ }^{38}$. Bitcoin'de her 1 saniyede 4 işlem yapılabilirken Ethereum' da bu sayı 15 işleme kadar çıkabilmektedir ${ }^{39}$.

Öte yandan, Ethereum ve Bitcoin Blokzincirlerinin madenciliklerinin ${ }^{40}$ arasında önemli farklılıklar vardır. Ethereum madenciliği ile Bitcoin madenciliğinde kullanılan algoritmalar ve altyapı farklıdır. Bu fark, pratikte, ortalama bir bilgisayarla Bitcoin madenciliğinin yapılmasını güçleştirirken Ethereum madenciliğinin sıradan bilgisayar ile yapılabilmesinin mümkün olmasınına yol açar. Ethereum'da yapılan işlemlerin mutabakat sistemleri "Proof of Stake (Hisse Kanıtı)" yani işlem mutabakatına, Bitcoin ise "Proof of Work ${ }^{41}$ (İş Kanıtı)" yani Emek İspatına tabidirr". İşlem ve onay mekanizmaları farklı olan bu algoritmalar bahse konu Blokzincilerde yapılan işlemlerin hızını ve onay sürelerini belirleyen unsurlardır.

Ethereum ve Bitcoin Blokzincilerinin arasında buraya kadar yer kısa verdiğimiz karşılaştırmalar, bu iki teknolojinin farklılıkları gösteren temel unsurlardır. Böylece Bitcoin ve Ethereum'un aslında iki farklı yapı olduğunu görülebilir. Bu iki değişik yapının temelindeki ortak

\footnotetext{
35 ÖZSEYHAN, Efe: Bitcoin vs Ethereum: Aradaki Fark Nedir?, https://muhabbit.com/bitcoin-vs-ethereum-aradaki-farknedir/ (Erişim Tarihi: 18.10.2020)

${ }^{36}$ Bkz. dipnot 18.

${ }^{37}$ UZER, Betül: "Sanal Para Birimleri”, TCMB Uzmanlık Yeterlilik Tezi, Ankara 2017, s.19,96.

${ }^{38}$ Cryptocompare, What is the Gas' in Ethereum?, November 18, 2016,

https://www.cryptocompare.com/coins/guides/what-is-the-gas-in-ethereum/ Erişim Tarihi: 12.09.2020)

${ }^{39}$ Bitcoin ve Ethereum Arasındaki Farklar, https://www.icrypex.com/tr/blog/bitcoin-ve-ethereum-arasindaki-farklar-nelerdir ve ayrıca bkz. https://www.bfmedia.io/sikca-sorulan-sorular/ethereumun-bitcoinden-farki-ne-01588732.html, (Erişim Tarihi: 10.10.2020); Ethereum'da akıllı sözleşmelerin kodları Bitcoin sistemindeki gibi işlem içerisine dahil edilmezken yani kendi hesabında var olurken, Ethereum'da ise kullanıcıların fon tuttukları ve bilgisayar üzerinde saklayabildikleri onaylanmış ve onaylanmamış işlem detayları görülebilmektedir.

40 Madencilik veya İngilizce ifadesiyle "mining", donanım ve yazılımların bir arada kullanılması suretiyle, karmaşık problemlerin çözülmesi, böylece madenci olarak adlandırılan kişilerin kripto para ile ödüllendirilmesi, kripto para transferlerinin kaydının ve onayının yapılması işlemlerini ifade etmektedir.

41 "İş kanıtı", bir kriptopara blok zinciri ağının üzerindeki işleme dair o ağ üzerindeki kullanıcıların fỉkir ve görüş birliğine ulaşmalarını sağlamayı amaçlayan algoritma türüdür. Satoshi Nakamoto tarafından Bitcoin Blokzincirindeki işlemlerin onaylanmasında üçüncü kişilere, yani aracı kurumlara ve mutabakat sistemlerine ihtiyaç duyulmaması için geliştirilmiştir. "Hisse kanıtı" ise kripto para transferleri için gerekli olan matematiksel problemleri "Iş Kanıtında" olduğu gibi cihaza ve elektrik gücüne değil, sahip olunan kripto para birimine göre yani hisseye göre işlem gücü ayırarak sağlayan bir algoritmadır. 42 KILIÇ, Şahin: Ethereum Nedir, Bitcoin ile Arasındaki Farklar Nelerdir?, (https://www.webtekno.com/ethereum-ilebitcoin-arasindaki-farklar-h38580.html , (Erişim Tarihi: 24.08.2020); Bitcoin madenciliğinin zorluklarından bir diğeri merkezi kurallarından biri olan Blok Ödülü (Block Award) uygulamasıdır. Buna göre, kripto para birimine göre veya zorluk derecesine göre değişebilen miktarlarda, blok madenciliği sırasında bir blokta başarıyla hesaplama yapan yani bitcoin veya diğer altcoinlerden birini bulan madenciye verilen ödüle Blok Ödülü denilmekte olup Blok Ödülü, ağda yeni Bitcoin'ler oluşturmanın tek yoludur. Bu şekilde oluşturulan Blok, zincire eklenir. Zaman damgası ile tarih bakımından sabitlenir. Kronolojik olarak değiştirilemez şekilde zincirdeki Blok oluşur.
} 
özellikler; doğrudanlık, merkeziyetsizlik, şeffaflık ve halka açıklıktır. İkisi de blokzincir olmasına rağmen, Ethereum ve Bitcoin blokzincirlerinin algoritmalarının ve güvenlik sertifikalarının farklı olması akıllı sözleşmeler bakımından temel belirleyicidir. Ethereum'da akılı sözleşme oluşturmak mümkündür. Bitcoin blokzincirinde değidlir. Bunun sebebi, Ethereum üzerinde bir kodun programlanmasının mümkün olması, Bitcoin Blokzincirinde ise olmamasıdır. Ethereum blokzincirinden evvel Bitcoin blokzincirinde sadece kripto para transferi yapılabilirken; Ethereum ile birlikte kullanıcılar blokzincir üzerinde Ether denilen kripto para transferini yapabildikleri gibi buna ek olarak Ethereum üzerinde yeni programlar yazabilme olanağına kavuşmuştur. Böylece Ethereum üzerinde yazılan bir program, sözleşmesel özellikler göstererek, dağıtık olarak çalışabilmektedir ${ }^{43}$. Nitekim; akıllı sözleşmeler, dağıtık defter kayıt teknolojisinde anlaşmalara dayanan işlemlerin gerçekleştirilmesini ifade eder. Hatta burada programlanmış sözleşmeye konu varlığın transferi otomatik gerçekleştirilmektedir. Akıllı sözleşmeler, kendi kendini okuyabilen, önceden belirlenen şartların gerçekleşmesi halinde harekete geçerek sözleşme konusu taahhütleri kendiliğinden gerçekleştiren, konu ve unsuruları bakımından kağıt üzerindeki sözleşmelerle aynı veya benzer nitelikler arz eden programlardir ${ }^{44}$.

Ak1llı sözleşme temelinde programdan oluşur. Bu nedenle basit bir protokolle oluşturulup kamuoyuna sunulan, herkesin katılımına açık projelerin fonlanmasında kullanılmaya son derece elverişlidir. Yani akıllı sözleşme, sadece tipik iki taraflı sözleşmeler için değil aynı zamanda çok taraflı sözlemeler için de uygundur. Halka açık proje finansman sözleşmeleri, kitlesel fonlama uygulamaları bu modelle kolayca hayata geçirilebilmektedir. Bu noktada, Ethereum'un 2014 yılından itibaren, kendi kendine ifa edebilen sözleşme konseptine elverişli bir yapı sunması etkilidir. 2016 yılında ortaya çıkan Decentralized Autonomous Organizations (DAO) bunun tipik bir örneğidir ${ }^{45}$. DAO, Ethereum üzerinde, şirketleşmemiş, merkezi olmayan, hiyerarşi veya bürokrasi içermeyen, Ethereum üzerinde Token adı verilen kritpo varlıklarla katılım sağlanarak proje finansmanından, oylamalara kadar farklı amaçlarla kullanılabilen kendi kendine çalışan akıllı sözleşmedir. DAO'da sistem açı̆̆ının kullanılmasıyla yaşanan hacking (yetkisiz erişim veya işlem) olayının getirdiği derin güven krizi dahi aracısız, doğrudan, merkeziyetsiz, otonom işlem ve sözleşmelere olan ilgiyi azaltmamış, bugünlerde DeFi (Decentralized Finance) adı verilen merkeziyetsiz finans uygulamalarının gösterdiği üzere akıllı sözleşmelerin sunduklarına ve sunabileceklerine dair ilgi kuvvetini arttırarak devam etmiştir ${ }^{46}$.

\section{Akıllı Sözlemelerin Yapısı, İşleyişi ve Örnek Uygulamalar}

Ethereum'un özelliklerinin başında kripto para transferi gelir. Ancak, Ethereum'un işlevi, sadece kripto para transferinden ibaret değildir. DAO örneğinde olduğu üzere, Ethereum blokzinciri pek çok farklı amaç için kullanılabilir. Bu fonksiyonlar kripto para transferini içererek veya bundan bağımsız şekilde herhangi dijital hizmetin farklı noktalardaki bilgisayarlar aracıllğıyla verilmesi şeklinde tasarlanabilir. Bunu mümkün kılan akıllı sözleşmelerdir. Bu durum, akıllı sözleşme kavramına ve konseptine olan ilgiyi arttırmaktadır. Ethereum ağında her biri farklı noktada yer alan bilgisayarlar, Szabo'nun otomat makinalarına benzerlik göstermektedir. Burada Ethereum ağına bağlı olan bilgisayarlar tıpkı otomatlar gibi, önceden belirlenen şartların varlığında yine önceden belirlenmiş bir işlemi yapmaya hazır şekilde programlanmıştır. Tıpkı otomatlar gibi. Szabo'nun bakış açısıdan farklı olan ise sözleşmenin ağ üzerinde kurulması, sözleşme konusu işin ağ üzerinde ifa edilmesidir. Açıklamak gerekirse; cihazların Ethereum ağı üzerinde birbirine bağlı olması gerekmektedir. İlaveten bu cihazlar, barındırdıkları herhangi bir bilgi veya para birimi verisini, ağ üzerinde çalışan ve taraflarının iradesi ile mutabakatlarına göre oluşturulmuş bir program aracılığıyla, önceden belirlenen şart ve sürelerde sözleşmenin diğer taraflarına gönderilebilmesi için hazır şekilde beklemektedir. Bu işleyişin mümkün olması; yani ağdaki bilgisayarların arasında yapılacak işlem veya ödemelerin yapılabilmesi, kaydedilebilmesi için, makinelerin kabul ettikleri, hepsi için ortak bir kurallar bütününe, sözleşmeye ihtiyaç bulunmaktaydı. İşte, Ethereum bunu sağlamıştır. Diğer bir ifadeyle, Ethereum, farklı fiziksel konumdaki çok sayıda bilgisayarın veya bilgisayar özelliği olan her nevi makinanın arasında yapılacak işlemler ve bu işlemlerin tanımlandığı akıllı sözleşmeler için ortak dil ve altyapı

\footnotetext{
${ }^{43}$ LEVI, Stuart D./LIPTON, Alex B.: An Introduction to Smart Contracts and Their Potential and Inherent Limitations, https://tinyurl.com/yaflq5qh, (Erişim Tarihi: 06.08.2020)

${ }^{44}$ UZER, s.26.

${ }^{45}$ Report of Investigation Pursuant to Section 21(a) of the Securities Exchange Act of 1934:

The DAO, Release No. 81207 / July 25, 2017, https://www.sec.gov/litigation/investreport/34-81207.pdf (Erişim Tarihi: 15.02.2020).

${ }^{46}$ ATZORİ, s.8 vd.
} 
platformu olarak geliştirilmiştir ${ }^{47}$.

Bugünkü anlamıyla Ethereum üzerinde çalışan akıllı sözleşmelerin işleyişi Ethereum'un geliştiricisi Vitalk Buterin tarafından şu şekilde izah edilmektedir: "Sözleşmeler bilgisayar diline dönüştürülmekte ve bloklara kaydedilmektedir. Dağıtık defterlere kopyalanan sözleşmelerde taraflar yüzde yüz anonim tutulurlar. Kod parçacığı, belirli görevler ve detaylar belirlenerek (zaman sınırı, nereden nereye ne gideceği gibi) hazırlanır. Zamanı geldiğinde de işlemi yerine getirmek için harekete geçer ve gerekli şartlar sağlanıyorsa işlem başarıyla tamamlanır yahut tamamlanmadan iptal edilir ${ }^{48 "}$. Mevcut yapısıyla akıllı sözleşmelerin sürekli edimli borç ilişkisi yaratan sözleşmelerde ödeme borcunun ifasında, finansal kiralamalarda ${ }^{49}$, emanet sözleşmelerinde $\left(\right.$ Escrow $\left.^{50}\right)$, tüketicinin seçimlik haklarını kullanmasının söz konusu olduğu sözleşmelerde ${ }^{51}$, çevrimiçi pazaryeri hizmetlerinde ${ }^{52}$, tarafların ürün veya hizmet temini amaciyla bir araya getirilmesini sağlayan mobil uygulama hizmetlerinde, taşıma ${ }^{53}$, sigorta ${ }^{54}$, bankacil1 ${ }^{55}$, kitle fonlaması projelerinde ${ }^{56}$ kulanılmaya oldukça elverişli olduğu ve halihazırda bir çok ürün ve hizmete özgülenerek kullanılmaya başlandığ 1 görülmektedir ${ }^{57}$.

\section{Akıllı Sözleşmelerin Hukuki Görünümü ve Geleceği}

Ethereum'un yaratıcısı Vitalik Buterin Ethereum üzerinde çalışan kod parçacıklarına Smart Contracts adını veren ilk kişi olarak bu konuda 2018 yılında başlayan hukuki tartışmalar üzerine attığı bir tweette; bu programa ve bu özelliğe Smart Contacts adını vermiş olmaktan pişman olduğunu ifade ederek, bu kod parçacıklarına daha teknik ve sıkıcı bir isim vermenin, belki de kalıcı senaryolar ("Persistent Scripts") ibaresini kullanmanın daha doğru olacağını ifade etmiştir ${ }^{58}$.

Ne var ki hem hukukçuların hem de bilişimcilerin, akıllı sözleşmelere dair 2018 yılından bu yana giderek artan ilgisi akıllı sözleşmeler alanındaki çalışmaların ve ilginin adeta öngörülmeyen, organik, zorunlu ve pek de planlanmayan boyutta gelişmesine, ilerlemesine ve gerçekten akıllı sözleşmelere olan ihtiyaca dair talebin somut olarak kendisini göstermesine yol açmıştır ${ }^{59}$.

47 SERT, Turan: Sorularla Blockchain, https://bkm.com.tr/wp-content/uploads/2015/06/Sorularlablockchain.pdf (Erişim Tarihi: 18.11.2020); Report of Investigation Pursuant to Section 21(a) of the Securities Exchange Act of 1934:The DAO, Release No. 81207 / July 25, 2017, https://www.sec.gov/litigation/investreport/34-81207.pdf (Erişim Tarihi: 15.02.2020); ABD'nin SPK'sına muadil olan SEC tarafıdnan incelenen bu DAO olayında; şirketleşmemiş kuruluş olan DAO'nun; bir Alman Şirketi olan Slock.it UG ("Slock.it")'in, Slock.it kurucu ortaklarının ve aracılarının; federal menkul kıymetler kanunların ihlal edip etmediğini araştırmıştır. Raporda, DAO, bilgisayar kodunda yer alan ve dağıtılmış hesap defteri veya Blockchain üzerinde çalıştırılan bir "sanal" kuruluşu tanımlanmıştır ve Merkezi Olmayan (Yerinden Yönetimli) Özerk Organizasyon örneği olarak anılmıştır. DAO, Slock.it ve Slock.it'in kurucu ortakları tarafından, DAO Tokens'in yatırımcılara satışı yoluyla varlıkların oluşturulmasını sağlamak, daha sonra bununla "projeleri" finanse etmek amacıyla ve kar amacı güden bir kuruluş olarak yaratılmıştır. DAO Tokens sahiplerinin ana kazanç hedefi, DAO Tokens kullanılarak yatırım yapılan projelerin elde edeceği başarılar ve DAO Tokens'larının ikincil pazarda alım satımlarının sağlanmasıdır.

${ }^{48}$ BUTERIN, Ethereum. Burada, akıllı sözleşmeler ve yapılan tüm işlemler dağıtık defterlerde tutulmakta olup bu bakımdan çok yüksek bir güvenlik ve dokunulmazlık özelliğine sahiptir.

${ }^{49}$ SHANKER, Macha: Use Case: Smart Contract for Lease Agreements using Blockchain Technology, International Journal of Scientific Research in Computer Science and Engineering, 7(6), 2019, s.3-6; Örnek bir uygulama için bkz. https://rentpeacefully.com/ (Erişim Tarihi: 24.10.2020)

${ }^{50}$ LYONS, Tom/COURCELAS, Ludovic/TIMSIT, Ken: "Legal and Regulatory Framework of Blockchains and Smart Contracts, Thematic Report", European Union Blockchain Observatory \& Forum, 27.09.2019 s.22, https://www.eublockchainforum.eu/sites/default/files/reports/report_legal_v1.0.pdf (Erişim Tarihi: 22.06.2020)

51 CUTTS, Tatiana: "Smart Contracts and Consumers", West Virginia Law Review, 122(2), 2019, http://dx.doi.org/10.2139/ssrn.3354272, s.4-6 (Erişim Tarihi: 22.09.2020).

52 Pazaryeri Akı1lı Sözleşme uygulama örnekleri için bkz. https://smartz.io/ (Erişim Tarihi: 26.11.2020). Ayrıca bkz. PAK, Calvin: A Deep Dive Into Marketplace Smart Contracts, https://medium.com/the-notice-board/a-deep-dive-into-marketplacesmart-contracts-587bbc8e9776, (Erişim Tarihi: 21.09.2020)

${ }^{53}$ Taşımacılıkta örnek bir uygulamalar için bkz. https://shipchain.io/, https://www.treum.io/ ve https://www.bita.studio/ (Erişim Tarihi: 14.11.2020)

${ }^{54}$ Sigorta sektöründe Akıllı Sözleşme uygulamasına dair bir örnek için bkz. https://nexusmutual.io/ (Erişim Tarihi: 09.09.2020) ve https://etherisc.com/ (Erişim Tarihi: 18.11.2020). Sigortacıllk sektöründe riskin gerçekleşmesiyle talebin sunulması ödemenin yapılmasının sağlanması için Akıllı Sözleşmenin harekete geçmesi şeklinde özetlenebilir. Bu, işlemlerde zaman kaybını azaltmayı ve insan unsurundan kaynaklanan hataların önüne geçmeyi hedefler.

55 Smart Contracts in Financial Services: Getting from Hype to Reality, https://www.capgemini.com/consulting-de/wpcontent/uploads/sites/32/2017/08/smart_contracts_paper_long_0.pdf (Erişim Tarihi: 11.11.2020); BLEMUS, s.10.

${ }^{56}$ DAO için bkz. ZICHICHI, Mirko/CONTU, Michele/FERRETTI, Stefano/D’ANGELO, Gabriele: LikeStarter: a Smartcontract based Social DAO for Crowdfunding, https://arxiv.org/pdf/1905.05560.pdf (Erişim Tarihi: 20.12.2020)

${ }^{57}$ SCHMITT/MLADENOW/STRAUSS/SCHAFFHAUSER-LINZATTI, s.194; BLEMUS, s.14; Örneğin Emria Token'lar1.

${ }^{58} \mathrm{https} / / /$ twitter.com/VitalikButerin/status/1051160932699770882

${ }^{59}$ Görüşümüze göre, bu durumun sebebi, Nick Szabo'nun, makalemizin en başında ifade ettiğimiz, güvene dayalı sözleşme yapmanın ve sözleşmenin yerine getirilmesinin muhatabın tasarrufuna veya iradesine bırakılmasının yarattığı zaafların yol açtığı problemlere dair tespitleridir. 
Bugünün dünyasının ticari gereksinimlerinin ve giderek artan hız ihtiyacının karşısında, akıbeti güvene ve muhatabın tasarrufuna bağlı olan sözleşmelerin de form değiştirmesi kaçınılmazdır. Roma Hukukuna dayanan, 19. yüzyılın başında kabul edilen kodifikasyonlarla şekillenen sözleşmeler hukuku kaçınılmaz ve derin bir değişimin eşiğindedir ${ }^{60}$. Dijital teknolojilerin ve elektronik ticaretin gündelik hayatımıza entegre ettiği otomatizasyon, bu değişimi desteklemektedir. Mortgage krizi gibi finansal krizlerin yol açtığı hukuki ve iktisadi güven kayıpları; tüketicilerin, satıcıların, taşıyıcıların, tacirlerin, ticaret şirketlerinin yapacakları sözleşmeleri, aracılara veya muhatapların iyi niyetine, onların irade ve insiyatifine bırakmak yönündeki eğilimlerini zayıflatmaktadır. Her ne kadar Vitalik Buterin, akıllı sözleşmenin sadece bir yazılım olan kod parçacığı olduğunu ifade etse bile bu konudaki ihtiyaç ve talep akıllı sözleşmelerin planlanmayan şekilde giderek yaygınlaşmasını kaçınılmaz olarak genişletmekte ve tetiklemektedir ${ }^{61}$.

Bitcoin Blokzincirinin taraflar arasında merkeziyetsiz varlık transfer edebilmeyi sağlayan protokol olmasına mukabil; Ethereum'da, hem kripto varlık transferi, hem de; kodlama modeli, güvenlik sertifikası ve algortimalarından kaynaklanan farklılıklardan ötürü, kendi kendini ifa eden akıllı sözleşmelerin yapılabilmesi mümkündür. Bu durum, yaşanan finansal krizler, artan aracılık maliyetleri, otomatize edilmiş hayata duyulan talepteki artış gibi faktörlerin etkisiyle, akıllı sözleşemeleri hukuk ve özellikle sözleşmeler hukuku bakımından dikkat çekici kılmaktadır ${ }^{62}$. Buna göre taraflar, aralarındaki mutabakatlara uygun bir kod programını Ethereum'un blokzincirine yerleştirerek belli bir zamanda, belli şartların gerçekleşmesi halinde bu şartları içerir işlemin tarafların bir eylem veya işlemi olmadan kendi kendini icra veya ifa edilmesini sağlayan bir sonucun ortaya çıkmasını sağlayabilir63. Buna mukabil blokzincir üzerinde geliştirilen Token'ların ve akıllı sözleşmelerin hukuki statüsünün yasal bakımdan tamamıyla netleştiğini söylemek hali hazırda mümkün değidir ${ }^{64}$. Bazı lokal yasal düzenleme girişimleri dışında ${ }^{65} \mathrm{ABD}^{66}$ veya $\mathrm{AB}^{67}$ de akıllı sözleşmelerin hukuki durumuna dair doğrudan veya özel bir yasal düzenleme bulunmamaktadır ${ }^{68}$. Bu

\footnotetext{
${ }^{60}$ ÇEKIN, s.325.

${ }^{61}$ Görüşümüze gore, sözleşmelerde taraflar, taksitli ödemelerde, finansal kiralamalarda, konut satış sözleşmelerinde, tüketici sözleşmelerinde, escrow sözleşmelerinde aslında hiçbir sözleşme adımını, ödemeyi, işin yapılmasını ve buna ilişkin zamana yayılan süreçleri yani sürekli edimli borç ilişki doğuran şarta bağlı sözleşme ilişkilerinin yerine getirilmesini ve ifasını diğer tarafın iradesine bırakmak istememektedirler. Zira, bir sözleşme ilişkisine giren tarafların, en az sözleşmenin şartlarında anlaşmaları kadar, bu şartları tam ve zamanında yerine getirileceğinden emin olmak yönündeki ihtiyaçları, özellikle son 10 20 yıla yayılan ekonomik krizlerin yaşandığı kürsel piyasada son derece belirgindir. Böylece taraflar, hem sözleşmeyi yaparken aracılara muhtaç olmamak, hem de sözleşme konusu edimlerin ifasının taraf iradesinin güvenilmezliğine teslim edilmemesi için sözleşmede bir otomasyona olan taleplerini karşılayacak tek aday Akıllı Sözleşme kavramıdır. Kendi kendini ifa, kendi kendini fesih, yapılmış ödemelerin kendiliğinden iadesi gibi çözümlerle öne çıkan akıllı sözleşmeler, sözleşmesel bir uyuşmazlığın yargı merciilerinde yüksek maliyet ve uzun zaman kayıplarından kurtulmak için de oldukça etkilidir. Basit bir görev - yetki uyuşmazlığının yıllar aldığı, faizin miktarı ve başlangıç tarihine dair hesaplamaların dahi oldukça uzun sürdüğü, uyuşmazlıkların uzmanlıklarına dair bir teyit mekanizması bulunmayan bilirkişiler, avukatlar veya hakimlerin yarattığı hak kaybı risklerinden korunması için de kendi kendini infaz edebilen, feshedebilen, varsa feshe istinaden yapılan ödemeleri iade edebilen, emanet veya hak ediş sistemlerindeki aracıların, emlakçı, avukat, noter, mahkeme gibi unsurların getirdği zaman ve maliyet giderlerini minimize eden akıllı sözleşmelere olan talep her geçen gün artacaktır.

62 KONASHEVYCH, s.2.

${ }^{63}$ ÇEKIN, s.323; Akıllı sözleşmeler, Ethereum ağındaki katılımcıların protokolden olan bir yazılımla aralarında yaptıkları bir işlemi karşılar. Yazılımda belirlenen şartlar ve bunların gerçekleşemsine dir veriler ise ifa için elzemdir. Her Akıllı Sözleșmede bu şartlar bulunmayabilir. Ancak şarta ve şartın veriye bağlı olduğu hallerde yazılımın dışarıdan veri teminine ihtiyaç duyacağı açıktır. İşte yazılımın borcun ifası için harekete geçmesi için gerek duyacağı bu dış bilgiler "Oracle" adı veri besleme sağlayan aracılara gereksinim duyar. Oracle, bir veri besleme ve doğrulama yazılımı olabileceği gibi dışsal merkezi bir veri tedarik noktası da olabilir. Bu ikincisi merkeziyetsizlik ve aracısızlık özelliklerinin tekrar sorgulanmasını gerekrtirir. ${ }^{64}$ Federal Reserve Board, Divisions of Research \& Statistics and Monetary Affairs, Distributed Ledger Technology in Payments, Clearing and Settlement, Finance and Economics Discussion Series, 2016-095, December 2016, s.28.

${ }^{65}$ BLEMUS, s.13-14 ve orada dipnot 200'de anılan Arizona House Bill 2417, Bölüm 2 Başlık 44'e eklenen yasal tanımıyla Akıllı Sözleşme; dağıtık, merkezi olmayan, paylaşılan ve çoğaltılmış bir defterde çalışan ve muhafaza altına alınabilen ve bu defterdeki varlıkların aktarılmasına talimat verebilen, olay odaklı bir program şeklinde tanımlanmıştır.

${ }^{66}$ ABD Emtia Vadeli İşlemler Ticaret Komisyonu (Commodity Futures Trading Commission) 2018`de yayınladığı rehberde, akı1lı sözleşmelerin kullanım usul ve esaslarına göre bankacıllk ve kara para aklama mevzuatı da dahil olmak üzere mevcut düzenlemelere tabi olabileceği ifade ederek özel düzenlemeye değil genel düzenlemelerin kıyasen uygulanmasına işaret etmiştir; Raporun tamamı içn bkz. CFTC, A Primer of Smart Contracts, s.25 2018, https://www.cftc.gov/sites/default/files/2018-11/LabCFTC_PrimerSmartContracts112718.pdf (Erişim Tarihi:21.10.2020); Ayrica bkz. KONASHEVYCH, s.4.

${ }^{67}$ European Parliamentary Research Service, "How Blockchain Technology Could Change Our Lives", In-Depth Analysis, February 2017, s.15'de AB Parlementosu Araştırma Birimi tarafından sunulan incelemede akıllı sözleşmeler ele alınmış ve incelenmişse de bu konuda yasal bir düzenleme tavsiyesi içermemektedir.

${ }^{68}$ İngiltere'de Parlemento nezdinde kurulan akıllı sözleşmelerin incelenmesine dair Komisyon ise akıllı sözleşmelerin değer ve potansiyeline işaret etmişse de bu alanda özel bir regülasyon yapılmasına dair çalışmalarını henüz sonuçlandırmamıştır. Komisyon çalışmaları hakkında bkz. Finance Magnates, Research for Reforms on Blockchain Smart Contract Laws Begins
} 
sebeple akıllı sözleşmelerin, sözleşmeler hukukunun genel ilkelerine tabi olduğunu söylemek hatalı olmayacaktır. Eklemek gerekir ki henüz gelişmesini sürdüren akıllı sözleşmelerin hukuki durumunu özel hükümlerle belirlemek için henüz erken aşamada olunduğu da gerçektir ${ }^{69}$. Buna göre, akı1ll sözleşmeleri hukuken değerlendirirken, en azından şimdilik, mevcut yasaları dikkate alarak, özel şekil şartlarına tabi olanlar hariç olmak üzere, yorum yapmak; yürürlükteki yasalara göre bir sözleşmenin varlığından bahsedilebilmesi için aranan asgari unsurları barındıran Ethereum kodlarının sözleşme olarak kabul edilmesinin önünde bir engel bulunmamaktadır. Kodlarla ifade edilen bu sözleşmelerin kendi kendini ifa etmesi ise bu sözleşmelerin akıllı sözleşme olarak adlandırılmasına ve nitelenmesine yol açmaktadır ${ }^{70}$.

\section{E. Akıllı Sözleşmelerin Önündeki Teknik ve Hukuki Zorluklar}

Akıllı Sözleşme kavramı, sunduğu çözümler ve sağladığı avantajlara mukabil birtakım teknik ve hukuki zorluklarla karşı karşıyadır. Her şeyden evvel akıllı sözleşmelerin Ethereum üzerinden yapılabilmesi için uygun altyapının ve donanımın yaygınlaşması ve kullanımının öğrenilmesi gereklidir. Hali hazırda buna uygun donanımın ve Ethereum üzerinde akıllı sözleşme programlama dilinin yaygınlaştığını söylemek mümkün değildir. Aynı sorun bu Sözleşmelerin elektronik sertifikalarla imzalanması gereksinimi sebebiyle elektronik imza araçlarının kullanım sıklıkla kullanılmaması bakımından da karşımıza çıkmaktadır. Kullanım tecrübesindeki zayıflık, akıllı sözleşmelere dair araçların saklanması ve korunmasına dair riskler de yaratmaktadır. Bu noktada Private Key'in (Özel Anahtarın) kaybedilmesi ve hacklenme (yetkisiz erişim ve yetkisiz işlem) akla ilk gelen teknik risklerdir ${ }^{71}$.

Hukuki açıdan ise önemli bir sorun, aynı zamanda akıllı sözleşmelerin olumlu bir yönü olarak da anılan değiştirilemezlik özelliğidir. Akıllı sözleşmelerin değiştirelemezliğinden dolayı mücbir sebep gibi durumlarda ne şekilde hareket edileceğine dair net bir çözüm veya cevap bulumamaktadır. Bugün yaşanan salgın hastalık gibi durumlards örneğin kira bedelleriyle ilgili uyarlama davaları gündeme gelmekte, bu gibi ihtilaflar yıllar süren hukuki tartışmalara konu olmaktadır. Akıllı sözleşmeler ile taraflar iradelerini "if that then that" yani "eğer şu şart gerçekleşirse buna istinaden şunu yap" şeklinde bir koda yazarlar. Sözleşme süresi içerisinde değişen şartlar, ortaya çıkan mücbir sebeplere mukabil kod sabittir. Tarafların ifayı ayıplı ya da eksik gerçekleştirmeleri, duruma uygun takdir hakkının kullanılacağı haller söz konusu olduğunda akıllı sözleşmelerin değiştirilemezliğinden ve geri alınamazlığından dolayı ortaya çıkacak yeni şartlarla ilgili henüz net bir çözüm bulunmamaktadır. Bu noktada, akıllı sözleşmelerin yapay zeka çözümleriyle ve büyük veriyle desteklenmesi akla gelmelidir. Ancak bu şekilde akıllı sözleşmelerin, beklentileri daha esnek ve başarılı bir şekilde cevaplayabileceği düşüncesindeyiz ${ }^{72}$.

Akıllı sözleşmelerle ilgili diğer tartışma ise kod ve kayıtların eksiksiz olmasına duyulan ihtiyaçtır. Akıllı sözleşme, ancak eksiksiz ve kayıtsız kodlarla faaliyet gösterebilir. Akıllı sözleşmelerin bugün için sahip oldukları teknoloji ve bu teknolojinin doğası gereği; kısmi ifa, faiz hesaplaması gibi konulara henüz tatmin edici cevaplar ve çözümler sunmadığı görülmektedir. Akıllı sözleşmeler şu an sadece Ethereum üzerinde çalıştıkları için ${ }^{73}$ bunların hukuki bir bakış açısıyla geliştirilmesinin önünde, Solidity gibi programlama dillerini bilen, algoritma yazabilen hukukçulara duyulan ihtiyaç da önemli bir problemdir.

Bir diğer zorluk, Public Blockchain üzerindeki sözleşmelerde gizliliğin sağlanmasıdır. Çünkü taraflar, sözleşmelere yansıttıkları bilgilerin her zaman şeffaf olmasını arzu etmeyebilir. Özellikle ticari bilgi ve verilerin gizli tutulmasını isteyebilir; bu bilgilerin herkes tarafından erişilebilir olmasından imtina edebilirler. Öte yandan Public Blokzincirde kullanıcılar akıllı sözleşmeleri okuyabilmekte ve bunlara çeşitli uygulamalarla erişebilmektedir. Akıllı sözleşmeler, bu durumdan ötürü, gizliliğin sağlanması amaciyla Private Blockchain'e ihtiyaç duyarlar.

in UK, 2018 https://www.financemagnates.com/cryptocurrency/regulation/research-for-reforms-on-blockchain-smartcontract-laws-begins-in-uk/ (Erişim Tarihi: 14.06.2020).

${ }^{69}$ LYONS/COURCELAS/TIMSIT, s.25-26.

70 UK Jurisdiction Taskforce, Legal Statement on Cryptoassets and Smart Contracts, November 2019, s.32-33, https://tinyurl.com/v4t8fbk (Erişim Tarihi: 14.08.2020); O'SHİELDS, s.186-187.

${ }^{71}$ PILAVCI, s.87. vd.

${ }^{72}$ O'SHIELDS, s.189.

${ }^{73} \mathrm{Bkz}$. Ethereum Virtual Machine (EVM): Ethereum üzerinde gönderilen programın çalışmasını sağlayan yapıdır. Ethereum üzerinde gönderilen program EVM tarafından dağıtık bir şekilde çalıştırılmaktadır. EVM Dünya'daki tüm bilgisayar düğümlerini birbirine bağlayan bu teknolojinin işletim sistemi olarak bilinen ve Ethereum'un merkeziyetsizliğini sağlayan algoritmadır (https://ethereum.org/en/developers/docs/evm/, Erişim Tarihi: 23.11.2020). 
Ak1llı sözleşmelerle ilgili zorluklar sadece hukuki olanlardan ibaret değildir. Teknik sorunlar da en az hukuki zorlukar kadar dikkat çekicidir. DAO kriziyle beraber akıılı sözleşmelerle ilgili yaşanan teknik tartışma derinleşmiş olup halen varlı̆̆ını korumaktadır ${ }^{74}$. DAO, ABD'de, Ethereum üzerinde akıllı sözleşme olarak hayata geçirilen ilk ve en kapsamlı kitlesel fonlama projesidir. Bu sebeple akıllı sözleşmelerin geleceği bakımından önemli bir yere örnektir. Akıllı sözleşme kitlesel fonlama için en uygun araçtır. Çok sayıdaki kişinin düşük meblağlarla katılarak bir projeyi, pay, ödül, hisse, ürün vb karşıllğı finanse ettikleri uygulamaya kitlesel fonlama denilmektedir. Bu projede, projenin sahipleri yoktur. Ortada bir şirket bulunmamaktadır. Tarafları belli değildir. Merkezi veya hiyerarşik bir işleyiş söz konusu değildir. DAO'da Ethereum üzerinde akıllı sözleşme ile kitlesel fonlama yapılmıştır. Katılımcılara Ether karşıllığ DAO Token verilmiş, bu Token oylamalarda veya proje finansmanında kullanılmak üzere üretilmiştir DAO kitlesel fonlamasına, çok kısa sürede 168 Milyon USD değerinde kripto paraya ulaşan bir katılım sağlanmıştır ${ }^{75}$. Ancak katılımcılardan birinin tesadüfen, fonlamadan yani akıllı sözleşmeden çıkmayı denemesi, "katılımımı iptal et ve yaptığım ödemeyi iade et" seçeneğini tıklamasıyla sistemde bir açık keşfedilmiştir. Böylece DAO’nun akıllı sözleşmesinden çıkmanın mümkün olduğu görülmüş ve katılımcı, bunu deneyerek başarmıştır. Katılımcı aynı zamanda akıllı sözleşmede önemli bir açı̆̆ 1 keşfetmiş ve aynı işlemi tekrar tekrar denemiştir. Akıllı sözleşmede, katılımcının ya sözleşmeden tek taraflı şekilde çıkamaması veya bunu tekrar edememesi gerekirdi. Ancak aynı kullanıcı bu işlemi tekrar tekrar yapmayı denediğinde, kısa süre içerisinde kitlesel fonlama uygulamasından çok miktarda, yaklaşık 50 Milyon USD değerinde kripto para aynı kullanıcıya gönderilerek bir sistemsel açık hacking ortaya çıkmıştı ${ }^{76}$. Açığın fark edilmesi üzerine Ether üzerinde müdahalede bulunulmuş, meşhur Ether Forku yani çatallanması yaşanmıştır ${ }^{77}$. Bu durum, akıllı sözleşme üzerinde teknik bakımdan ve kodlama bakımından yaşanabilecek eksikliklerin ve hacklerin ağır ihlallere sebep olabileceğini göstermiştir ${ }^{78}$. Dolayısıyla programlama hatasının geri alınamaması, uyarlama yolunun ve emprevizyon olanağının şu an için mevcut olmaması, faiz hesaplarının bulunamaması, duruma uygun takdir hakkının kullanılabilmesine kapalı yapısı, sabit ve değişmez ${ }^{79}$ olması, gizlilik ve şeffaflık ile ilgili tereddütler akıllı sözleşmelerin bugün arz ettikleri yapılarının dikkat çeken teknik ve hukuki zorukları oluşturmaktadır ${ }^{80}$.

\section{SONUÇ}

Sözleşmeler hukuku alanındaki kurallarının geçmişi yüzyıllara dayanmaktadır. Sözleşmelerin temelinde ise irade serbestisi ve irade serbestisini harekete geçiren güven yatmaktadır. Öte yandan sözleşmelerin kurulmasında ve edimlerin ifasında en zayıf ve riskli halka da irade serbestisi ve güven asimetrisidir. Güvene dayalı sözleşmelerin ifa noktasında tabi oldukları riskler finansal krizlerle belirginleşmektedir Sözleşmelerin kurulmasında veya ifasında aracılara duyulan gereksinim ve bunun yarattığı maliyetler sürdürülebilir olmayıp ayrıca güvene dayalı zaafları da arttırmaktadır. Uzun süren, oldukça pahalı ve genellikle tatmin edici olmaktan uzak kalan yargılama süreçlerinin yol açtığı zaman ve masraf maliyetlerinde göz önünde bulundurulunca, bu sorunların çözümünün teknolojide ve akıllı sözleşmelerde aranması kaçınılmazdır. Diğer bir ifadeyle akdin kuruluş ve ifa anında tek belirleyicinin güven ve irade olması sözleşmelerin en büyük zaaflarıdır. Bu zaafların ve risklerin yarattığı boşlukları gidermenin yolu ise teknolojide aranmaktadır. Blokzincir tabanlı, kendi kendini ifa veya feshedebilen akıllı sözleşmelerin geliştirilmesine bu bakımdan oldukça ilgi duyulmaktadır. Bu ilgi ve ihtiyacı karşılamaya en büyük ve en yakın aday Ethereum tabanlı akıllı sözleşmelerdir. Blokzincirin, nitelik ve özellikleri öğrenildikçe, kodlama bilen hukukçular çoğaldıkça akıllı sözleşmelerin kullanımımın önümüzdeki yıllarda giderek olgunlaşacağını ve artacağını düşünmekteyiz. Akıllı sözleşmelerin beklenen etkisy ve faydayı sağlayabilmesi için yazılım ve donanım yeterliliği, kullanımın yaygınlığı ve kullanıcı tecrübesinin oluşması önemlidir. Akıllı sözleşmelerdeki güvenlik sorunları, şeffaf yapısının gizlilik ihtiyacı bakımından yarattı̆̆ çekinceler, DAO örneğindei gibi hacklenme riskleri,

\footnotetext{
${ }^{74}$ LYONS/COURCELAS/TIMSIT, s.27.

${ }^{75}$ SEC, s.2-4.

${ }^{76}$ KONASHEVYCH, s.13; CUTTS, s.22-35.

77 DAO hacking ve sonrasında DAO'nun çöküşünün etkisiyle, Ethereum iki farklı Blokzincire ayrıldı. Bu ayrılmaya çatallanma denilmektedir. Bu şekilde çatallanma sonucu oluşan versiyon Ethereum (ETH), orijinal olan ise Ethereum Classic (ETC) olarak varlığını devam ettirmektedir.

${ }^{78}$ BLEMUS, s. 15.

${ }^{79}$ Akıllı anlaşmalar yürütüldüğünde yani harekete geçerek bir sonucu sağladığında, değiştirilemeyecek günlük kayıtları oluşturulur.

${ }^{80}$ SCHMITT/MLADENOW/STRAUSS/SCHAFFHAUSER-LINZATTI, s.194; Bugün için Smart Contracts kullanımına en uygun ve yaygın alanlar olarak sigortacılık, araç kiralama, seyahat sözleşmeleri, hak ediş ödemeli sözleşmeler gösterilmektedir
} 
geri alınmazlık ve uyarlama yapılamaması ise gözden kaçırılmaması gereken tereddüt noktalarıdır. Yapay zeka ve doğru veri ile desteklenmesi halinde akıllı sözleşmelerin önümüzdeki yıllarda sözleşmeler hukukunu önemli ölçüde etkileyecek ve değiştirecek bir altyap1 ve teknoloji olmaya aday olduğunu ifade etmek mümkündür. Özel şekil şartlarına tabi olan istisnalar bir yana konulacak olursa, bir sözleşmenin varlığından bahsedilmesi için gerekli asgari yasal unsurları içeren ve kodlardan oluşan bu programların hukuken geçerli ve bağlayıcı birer akıllı sözleşme olarak kabul edilmesinin önünde bir engel bulunmamaktadır.

\section{KAYNAKÇA}

A\&M Records, Inc. v. Napster, Inc., 239 F.3d 1004 (9th Cir. 2001), https://www.copyright.gov/fairuse/summaries/a\&mrecords-napster-9thcir2001.pdf (Erişim Tarihi: 24.09.2020).

ATZORI, Marcella: Blockchain Technology and Decentralized Governance: Is the State Still Necessary? (December 1, 2015), s. 8-10, http://dx.doi.org/10.2139/ssrn.2709713 (Erişim Tarihi: 07.09.2020), p. 1-37

BFMEDIA, Bitcoin'in Ethereum'dan Fark1 Ne?, https://www.bfmedia.io/sikca-sorulan-sorular/ethereumunbitcoinden-farki-ne-01588732.html, (Erişim Tarihi: 10.10.2020).

BLEMUS, Stéphane: "Law and Blockchain: A Legal Perspective on Current Regulatory Trends Worldwide (January 17, 2018)". Revue Trimestrielle de Droit Financier (Corporate Finance and Capital Markets Law Review) RTDF No4-2017 - December 2017, http://dx.doi.org/10.2139/ssrn.3080639 (Erişim Tarihi: 18.11.2020), p.1-15.

BROWNSWORD, Roger: Regulatory Fitness: "Fintech, Funny Money and Smart Contracts", European Business Organization Law Review, 20(5), 2019, https://core.ac.uk/download/pdf/195262705.pdf. (Erişim Tarihi: 09.12.2020), p.1-27.

BUTERIN, Vitalik: "Bitcoin Is Not Quantum-Safe, And How We Can Fix It When Needed". Bitcoin Magazine, https://bitcoinmagazine.com/articles/bitcoin-is-not-quantum-safe-and-howwe-can-fix1375242150 (Erişim Tarihi: 21.08.2020).

BUTERIN, Vitalik: "Ethereum: A Next-Generation Cryptocurrency and Decentralized Application Platform (Ethereum)", Bitcoin Magazine, https://Bitcoinmagazine.com/articles/ Ethereum-nextgeneration-cryptocurrency-decentralized-application-platform-1390528211 (Erişim Tarihi: 16.10 .2020$)$.

Cap Gemini: Smart Contracts in Financial Services: Getting from Hype to Reality, https://www.capgemini.com/consulting-de/wp-

content/uploads/sites/32/2017/08/smart_contracts_paper_long_0.pdf (Erişim Tarihi: 11.11.2020).

Commodity Futures Trading Comission: A Primer of Smart Contracts, 2018, https://www.cftc.gov/sites/default/files/2018-

11/LabCFTC_PrimerSmartContracts112718.pdf (Erişim Tarihi: 21.10.2020).

CHOHAN, Usman W.: A History of Bitcoin (September 30, 2017), http://dx.doi.org/10.2139/ssrn.3047875 (Erişim Tarihi: 15.10.2020), p.1-11.

CROSBY, Michael/PATTANAYAK, Pradan/VERMA, Sanjeev/KALYANARAMAN, Vignesh: "BlockChain Technology: Beyond Bitcoin", Applied Innovation Review, (2), June 2016, https://j2-capital.com/wp-content/uploads/2017/11/AIR-2016-BlockChain.pdf (Erişim Tarihi: 11.09.2020).

CRYPTOCOMPARE: "What is the 'Gas' in Ethereum?", November 18, 2016, https://www.cryptocompare.com/coins/guides/what-is-the-gas-in-ethereum/ (Erişim Tarihi: 12.09 .2020$)$.

CUTTS, Tatiana: "Smart Contracts and Consumers", West Virginia Law Review, 122(2), 2019, http://dx.doi.org/10.2139/ssrn.3354272 (Erişim Tarihi: 22.09.2020), p.1-52.

ÇEKIN, Mesut Serdar: "Borçlar Hukuku ile Veri Koruma Hukuku Açısından Blockchain Teknolojisi ve Akıllı Sözleşmeler: Hukuk Düzenimizde Bir Paradigma Değişimine Gerek Var Mr?’ İstanbul Hukuk Mecmuasi, 77(1), 2019, s.315-341.

DIMITROPOULOS, Georgios: "The Law of Blockchain", Washington Law Review, 95(3) 2020, p.1117-1192

European Parliamentary Research Service: "How Blockchain Technology Could Change Our Lives", In-Depth Analysis, February 2017.

Federal Reserve Board, Divisions of Research \& Statistics and Monetary Affairs: Distributed Ledger Technology in Payments, Clearing and Settlement, Finance and Economics Discussion Series, 2016-095, December 2016.

Finance Magnates: Research for Reforms on Blockchain Smart Contract Laws Begins in UK, 2018,https://www.financemagnates.com/cryptocurrency/regulation/research-forreforms-on-blockchain-smart-contract-laws-begins-in-uk/ (Erişim Tarihi: 14.06.2020). 
HÄRDLE, Wolfgang K./HARVEY, Campbell R./REULE, Raphael C. G.: Understanding Cryptocurrencies (March 26, 2019), http://dx.doi.org/10.2139/ssrn.3360304 (Erişim Tarihi: 18.09.2020), p. 1-39.

ICRYPEX: Bitcoin ve Ethereum Arasındaki Farklar, https://www.icrypex.com/tr/blog/bitcoin-ve-ethereumarasindaki-farklar-nelerdir (Erişim Tarihi: 10.10.2020).

KAKAVAND, Hossein/KOST DE SEVRES, Nicolette/CHILTON, Bart: The Blockchain Revolution: An Analysis of Regulation and Technology Related to Distributed Ledger Technologies (January 1, 2017), http://dx.doi.org/10.2139/ssrn.2849251, (Erişim Tarihi: 14.10.2020), p.1-27.

KARAMANLIOĞLU, Argun: "Concept of Smart Contracts - A Legal Perspective”, Kocaeli Üniversitesi Sosyal Bilimler Dergisi, (35), 2018, s.29-42.

KILIÇ, Şahin: Ethereum Nedir, Bitcoin ile Arasındaki Farklar Nelerdir?, (https://www.webtekno.com/ethereum-ile-bitcoin-arasindaki-farklar-h38580.html , (Erişim Tarihi: 24.08.2020).

LEVI, Stuart D./LIPTON, Alex B.: An Introduction to Smart Contracts and Their Potential and Inherent Limitations, https://tinyurl.com/yaflq5qh, (Erişim Tarihi: 06.08.2020).

LYONS, Tom/COURCELAS, Ludovic/TIMSIT, Ken: "Legal and Regulatory Framework of Blockchains and Smart Contracts, Thematic Report", European Union Blockchain Observatory \& Forum, 27.09.2019, https://www.eublockchainforum.eu/sites/default/files/reports/ report_legal_v1.0.pdf (Erişim Tarihi: 22.06.2020).

OĞUZMAN, M. Kemal/ÖZ Turgut, Borçlar Hukuku Genel Hükümler, C. I, İstanbul, 2020.

O'SHIELDS, Reggie: Smart Contracts: "Legal Agreements for the Blockchain”, North Carolina Banking Institute, 21(1), 2017, p.1-19.

ÖZSEYHAN, Efe: Bitcoin vs Ethereum: Aradaki Fark Nedir?, https://muhabbit.com/bitcoin-vs-ethereumaradaki-fark-nedir/ (Erişim Tarihi: 18.10.2020).

PAK, Calvin: A Deep Dive Into Marketplace Smart Contracts, https://medium.com/the-notice-board/a-deepdive-into-marketplace-smart-contracts-587bbc8e9776, (Erişim Tarihi: 21.09.2020).

PILAVCI, Ezgi Elife: “The Regulation of Smart Contracts: Law, "overnance and Practice”, İstanbul Bilgi Üniversitesi, Lisansüstü Programlar Enstitüsü - Bilişim ve Teknoloji Hukuku Yüksek Lisans Programı (Yayınlanmamış Yüksek Lisans Tezi), İstanbul 2019.

RASKIN, Max: "The Law and Legality of Smart Contracts", Georgetown Law Technology Review, (305), 2017, https://ssrn.com/abstract=2959166 (Erişim Tarihi: 22.10.2020), p.305-340.

SCHMITT, Gregor/MLADENOW, Andreas/STRAUSS, Christine/SCHAFFHAUSER-LINZATTI, Michaela: Smart Contracts and Internet of Things: A Qualitative Content Analysis using the Technology-Organization-Environment Framework to Identify Key-Determinants, https://www.sciencedirect.com/ (Erişim Tarihi: 22.10.2020).

SEC: “The DAO” Investigative Report, 25 Temmuz 2017, https://www.sec.gov/litigation/investreport/3481207.pdf (Erişim Tarihi: 17.06.2020).

SERT, Turan: Sorularla Blockchain, https://bkm.com.tr/wp-content/uploads/2015/06/Sorularlablockchain.pdf (Erişim Tarihi: 18.11.2020).

SHANKER, Macha: "Use Case: Smart Contract for Lease Agreements using Blockchain Technology", International Journal of Scientific Research in Computer Science and Engineering, 7(6), 2019, p.1-9.

SZABO, Nick: Smart Contracts (1994), www.fon.hum.uva.nl/rob/Courses/InformationInSpeech/ CDROM/Literature/LOTwinterschool2006/szabo.best.vwh.net/smart.contracts.html (Erişim Tarihi: 15.10.2020).

SZABO, Nick: Smart Contracts: Building Blocks for Digital Markets, https://nakamotoinstitute.org/the-ideaof-smart-contracts/ (Erişim Tarihi: 10.10.2020).

ŞEN, Faruk: "Dağıtık Kayıt Teknolojisi”, Gümrük ve Ticaret Dergisi, 6(17), 2016, s.84-95.

TAŞKIN Zeynep Damla: Sözleşmenin Kurulması, İstanbul 2020.

TBV Blokchain Turkey Platformu, Blokzinciri Teknolojisi Terminoloji Çalışması, Hukuk, Düzenlemeler ve Kamu İlişkileri Çalışma Grubu Raporu, İstanbul 2019.

TEVETOĞLU, Mete: ICO (İlk Dijital Para Arzı) ve Yatırımcının (Katılımcının) Korunması, Sektörel Bazda Tüketici Hukuku Uygulamaları 2020, İstanbul 2020, s.83-137.

THIBAULT, Schrepel: "Collusion by Blockchain and Smart Contracts", Harvard Journal of Law and Technology, 33(1), 2019, https://ssrn.com/abstract=3315182 (Erişim Tarihi: 16.10.2020), p.118-166.

TUNALI, Halil: “Mortgage Sistemi: Temelleri, Gelişimi ve Krizi”, İstanbul Üniversitesi İktisat Fakültesi Mecmuas1, 58(1), 2011, s.99-124.

UK Jurisdiction Taskforce, Legal Statement on Cryptoassets and Smart Contracts, November 2019, https://tinyurl.com/v4t8fbk (Erişim Tarihi: 14.08.2020). 
UZER, Betül: Sanal Para Birimleri, TCMB Uzmanlık Yeterlilik Tezi, Ankara 2017.

ZICHICHI, Mirko/CONTU, Michele/FERRETTI, Stefano/D'ANGELO, Gabriele: LikeStarter: a Smartcontract based Social DAO for Crowdfunding, https://arxiv.org/pdf/1905.05560.pdf (Erişim Tarihi: 20.12.2020).

Web siteleri

https://ethereum.org/en/developers/docs/evm/ (Erișim Tarihi: 23.11.2020).

https://etherisc.com/ (Erişim Tarihi: 18.11.2020).

https://nexusmutual.io/ (Erişim Tarihi: 09.09.2020).

https://shipchain.io/, (Erişim Tarihi: 14.11.2020).

https://smartz.io/ (Erişim Tarihi: 26.11.2020).

https://twitter.com/VitalikButerin/status/1051160932699770882

https://www.bita.studio/, (Erişim Tarihi: 14.11.2020).

https://www.Ethereum.org/beginners/ (Erişim Tarihi: 20.10.2020).

https://www.treum.io/, (Erişim Tarihi: 14.11.2020). 